\title{
Biases in International Portfolio Allocation and Investor Protection Standards
}

\begin{abstract}
Economic reasoning suggests that financial globalization that encourages optimal international portfolio investments should improve investor protection standards (IPS) of a country. In practice, however, investors manifest varying degrees of suboptimal international portfolio allocations. Using a panel dataset covering 44 countries spanning over 15 years we examine whether suboptimal equity portfolio allocation in part is associated with the cross-country variations in IPS. Consistent with economic reasoning we find robust indications that international portfolio allocation may play an important role in the development of IPS. More specifically, the quality of IPS improves with higher degrees of optimal international equity portfolio allocation of domestic and foreign investors.
\end{abstract}

JEL classification: F2, G1, G3

Key words: financial globalization; investor protection standards; equity home bias; equity foreign bias. 


\section{Introduction}

Economic conjecture notes that financial globalization affects the factor productivity of a country by promoting better corporate governance and signalling a higher quality of state

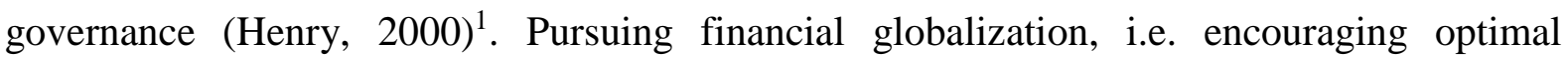
international portfolio allocations that integrates local with world capital markets may thus have a lasting effect on the improvement of investor protection standards (IPS) ${ }^{2}$. With respect to what should be the optimal portfolio allocations, finance theory suggests that investors should hold the world market portfolio to optimise their expected utilities (see Chan et al., 2005). However, studies note that both domestic and foreign investors substantially deviate from holding optimal international portfolios (see, for example, Lau et al., 2010). Such deviations are referred to as home and foreign biases in international portfolio allocations. Home bias refers to the phenomenon in which domestic investors over-invest in the home market relative to the theoretical conjecture, thus leaving a significantly lower share of the country's investable assets to foreign investors. On the other hand, foreign bias indicates that foreign investors tend to either over or underweight foreign markets relative to implied benchmarks (see Cooper et al., 2015 for an excellent review). While substantial evidence exists on why home and foreign biases exist, much less is known about the implications of such biases. In this study we investigate whether the puzzle of home and foreign bias carries any consequences for the differing states of IPS observed across the world.

Empirical evidence concludes that the prevalence of home and foreign biases explains the degree of international integration/segmentation of the domestic equity markets vis-à-vis the world capital markets (see Janakiramanan, 1986; Lau et al., 2010). This suggests that higher home bias reflects a lower degree of financial globalization, while higher foreign bias implies

\footnotetext{
${ }^{1}$ As argued by La Porta et al. (1997) it is axiomatic that standards of investor protection regulations and practices are pivotal for the welfare of corporates and countries.

${ }^{2}$ Bonaglia et al. (2001) also argue that allowing optimal foreign portfolio investments should improve the quality of IPS.
} 
a higher degree of financial globalization (see Lau et al., 2010 for a theoretical analysis). Consequently, greater home bias implies a relatively closed and less integrated economy with a lower presence of foreign investors. Alternatively, in a relatively open and financially integrated market economy, higher foreign bias signifies a greater presence of foreign investors. Since varying degrees of home and foreign biases reflect varying depths of foreign portfolio investments, studies document several channels through which foreign investors may influence corporate and state governance practices.

With respect to corporate governance Kang and Kim (2010) note that foreign investors particularly institutional investors play an influential role in domestic governance practices by employing various governance tactics. Such disciplinary methods may take the form of hostile takeover threats, proxy contests, expressing opposition to or attempting to amend anti-takeover provisions $^{3}$, initiating efforts to seek representation on the target boards, threatening the replacement of top executives and demanding asset downsizing. Likewise, Boubakri et al. (2005) note that foreign ownership could lead to improvements in the post-privatization performance of newly privatized firms because foreign investors normally demand high information disclosure standards, inject funds into newly privatized firms and, for the sake of their reputation, maintain stern control of managers' action. Kho et al.'s (2009) theoretical framework argues that foreign investors, particularly those from countries with better investor protection institutions, become valuable inside monitors as the laws of their home countries restrict their ability to consume private benefits made by other insiders. On the empirical front, using data on China's split-share structure reform, Huang and Zhu (2015) show that involving foreign institutional investors in corporate governance practices can significantly lower the possibility of expropriation by the controlling shareholders in emerging markets.

\footnotetext{
${ }^{3}$ For example, in 2005 The Children's Investment Fund (TCI), a UK-based hedge fund which had a major share of the German Deutsche Börse forced the management to stop a takeover of the London Exchange which led to the resignation of both the chief executives (Economist, 2008).
} 
With reference to the standard of state governance, economists remark that competition for foreign financial resources compels policymakers to reform the state and corporate governance practices ${ }^{4}$ (see Errunza, 2001). With respect to state governance, Stulz (2005) argues that financial globalization makes it difficult for the state itself to expropriate investors as it risks losing the much needed foreign investments if it does not heed the demands of foreign investors $^{5}$. Similar sentiments are echoed by Rajan and Zingales (2003) who conjecture that competition for financial resources becomes stronger when foreign investors become involved in the domestic economy. As a result, the growing interest of foreign investors drives reform ${ }^{6}$ in the domestic investor protection regulations (see Rajan and Zingales, 2000). For example, responding to foreign investors' pressure, domestic regulatory bodies signal their intention to improve the quality of governance through the adoption of international accounting standards. Errunza (2001) also posits that with their increasing interest, foreign investors demand the formulation and observance of regulations, which compels corporates to disseminate timely and relevant information to the investor fraternity. Using data from emerging markets, Huang and Zhu (2015) show that the flow of foreign institutional investors help promote the marketbased principle of corporate governance, thus reducing the "twin agency" problem associated with state ruler's discretion.

\footnotetext{
${ }^{4}$ For example, in 2007 Japan implemented the Financial Instruments and Exchange Law, which amended or abolished many laws that regulated foreign securities firms and was intentionally based on the UK's Financial Services Authority's framework (Report by Herbert Smith, 2008 on Contemporary issues facing financial services institutions in Asia, http://documents.lexology.com/cd07ed3a-b7d3-4b63-ab50-bcffa0e01dc1.pdf)

${ }^{5}$ TCI initiated legal action against the Indian government under the provisions of bilateral investment treaties between India and UK over the under-pricing of coal by Coal India Limited, in which TCI holds a 1\% stake (see: http://www.business-standard.com/article/economy-policy/tci-starts-legal-action-against-indian-govt-under-ukcyprus-treaties-112032900095_1.html).

${ }^{6}$ Demand from foreign investors may also lead to withdrawal/deferment of reforms. For example, in March 2012 India announced the imposition of controversial general anti-avoidance rules (GAAR) on transactions made by foreign investors, without much clarity, to be effective from 1 April 2012. Foreign portfolio investors demanded immediate reversal of the reform. After intense pressure from foreign institutional investors, India deferred the introduction of GAAR until April 2013 and after further negotiations it was postponed until 2016 (Source: Financial Times, 7 May 2012 and 3 September 2012)
} 
The above discussion convincingly underlines the importance of foreign investments for the development of corporate and state governance. Since a higher level of home (foreign) bias refers to a lower (greater) presence of foreign investors, in this study we hypothesize that a greater degree of home (foreign) bias should be related to a lower (higher) quality of IPS. As noted earlier, a vast body of literature is devoted to explaining the causes of home and foreign biases $^{7}$. However, studies investigating the implications of home and foreign biases is highly limited. More importantly, to the best of our knowledge, there is no study that examines the implications of home and foreign biases on the quality of IPS. Using a sample of 44 countries over the period from 2001-2015 and running a series of robustness checks, including the use of a shock-based approach, our study reports the following two important findings.

First, the results suggest that suboptimal international portfolio allocations of domestic and foreign investors may play a critical role in improving the quality of IPS. Specifically, markets where investors observe a higher degree of home bias (i.e. lower presence of foreign investors) are associated with poor quality of corporate and state IPS. Similarly, relative to more closed markets (lower foreign bias), countries that allow/attract greater foreign portfolio investments (greater foreign bias) are related a higher level of IPS. These findings hold after carefully accounting for several other possible determinants of IPS and for the potential reverse causality arising from the possibility that improvement in investor protection may cause a higher presence of foreign investors. In summary, the results support the view that financial globalization that encourages optimal international portfolio investments may carry significant implications for the development of corporate and state IPS.

Second, consistent with the findings reported by Chan et al. (2005), our results show that the developed markets generally exhibit a lower level of home bias compared to emerging markets. We also find that most developed countries experience stronger positive foreign bias,

\footnotetext{
${ }^{7}$ See Cooper et al. (2015) for an extensive survey on the causes of home and foreign biases.
} 
i.e. these countries are preferred by international investors compared to the emerging markets. However, we further contribute to this strand of literature by providing new evidence of biases in the cross-country asset allocations made by sophisticated global fund managers who are ideally expected to achieve optimal global diversification. This evidence uncovers that the manifestation of investment biases is not only observed in the aggregate and macro data, which may include singly country or regional funds, but also in the investment behaviour of the most sophisticated global fund managers.

Our study adds to two different strands of literature. First, and as noted above, to the best of our knowledge, this is the first study to examine the effect of suboptimal international portfolio allocation on the quality of IPS. Our study is remotely related to Lau et al. (2010) who also demonstrate the implications of home and foreign biases. However, their focus is on the level of cost of capital, whereas our study examines the influence of home and foreign biases on the quality of IPS. Few studies that investigate the determinants of investor protection are focused on the role of economic openness, not on financial openness. For example, Islam and Montenegro (2002) demonstrate that trade openness is positively associated with institutional quality but they do not investigate the effect of financial openness. Similarly, Busse and Gröning (2009) also demonstrate the importance of trade liberalization on good governance practices but, again, do not account for financial openness.

Second, the results of our study also add to the growing debate which states that the impact of international diversification and consequent risk sharing benefits should not be limited to cost of capital and growth responses (Kose et al., 2010). Rather, the beneficial results should be examined through the influence of financial globalization on factor productivity, such as improvement of micro and macro institutional quality, including corporate and state governance. 
The remaining structure of the paper is as follows. Section 2 describes the data. Section 3 presents and discusses the empirical results, and section 4 concludes the paper.

\section{Data}

In this section we first describe the four different country-level IPS measures, followed by the description of home and foreign bias measures (i.e. measures of suboptimal international diversification). Finally, following the literature we briefly discuss the control variables included in our analyses.

\subsection{Proxies of Investor Protection Standards}

In their seminal paper La Porta et al. (1997) emphasize the importance of institutions and the legal environment in protecting the interests of minority shareholders. They note that the quality of country level IPS is highly correlated with the protection offered to corporate investors, particularly to minority shareholders. La Porta et al. (1999) define good governance as one that protects property rights of economic agents, keeps regulations light, is clean, and democratic. Good governance relates to safeguarding the property rights by formulating effective law, facilitating a conducive environment of contract enforcement and refraining from expropriation. As such, our study employs four measures of IPS capturing the quality and practice of the different dimensions of firm and country level investor protection rights.

\subsubsection{Firm-level Corporate Governance Measure}

The first investor protection measure we use is the composite index representing the firm-level corporate governance (Firm_Gov). We obtain the data from two different sources. For the developed markets we secure the dataset from Aggarwal et al. (2011). This measure reflects firm level IPS that specifically captures the governance standards of firms across 23 
countries $^{8}$ for the period 2003-2008. For each firm in each country ${ }^{9}$ RiskMetrics database gathers information on governance attributes from firms' annual reports, regulatory filings, and their websites. Aggarwal et al. (2011) use this dataset and examine 41 firm-level governance attributes common to both U.S. and non-U.S. firms. The attributes cover four broad subcategories: (1) Board (24 attributes), (2) Audit (three attributes), (3) Anti-takeover provisions (six attributes), and (4) Compensation and ownership (eight attributes). A value of one is assigned to each attribute if the firm meets the minimally acceptable standard and zero otherwise. The index is then expressed as a percentage. For example, if a firm satisfies the entire 41 attributes standard, then it receives a score of $100 \%$.

For the 21 emerging markets, we obtain similar firm level rating data from Alliance Bernstein Capital Emerging Market Universe (ABCEMU). ABCEMU includes a firm in their database if the firm is a constituent of domestic stock market indexes compiled by a major index provider of the country, primarily Morgan Stanley Capital International (MSCI), comprising $70-85 \%$ of the market capitalization. The rating assigned to each firm is based on a set of 58 questions with the score being a binary answer to yes or no. The survey is completed by specialist analysts domiciled in the same region/country. The questionnaires are based on seven different attributes comprising different weights. ${ }^{10}$ The attributes are: information disclosure (7\%), management access and fair disclosure (11\%), accounting (12\%), value creation (22\%), board and shareholder structure (22\%), capital management and ethics (13\%) and social responsibility and other (13\%). We aggregate the firm level data for the developed and emerging markets and rescale them on $0-100 \%$ to generate country level ratings.

\footnotetext{
${ }^{8}$ The 23 countries included are all developed markets; Australia, Austria, Belgium, Canada, Denmark, Finland, France, Germany, Greece, Hong Kong, Ireland, Italy, Japan, the Netherlands, New Zealand, Norway, Portugal, Singapore, Spain, Sweden, Switzerland, the United Kingdom and the United States.

${ }^{9}$ Please refer Aggarwal et al. (2011, page. 157) for details of the number of firms used for each country.

${ }^{10}$ See Morey et al. (2009) for further details of the index.
} 


\subsubsection{Investment Profile Index}

The second measure of IPS we incorporate is referred as investment profile (Inv_file) index. This country level rating index is obtained from Political Risk Services' (PRS) International Country Risk Guide reflecting governments' attitude towards inward foreign investment (see Bekaert et al., 2007). The index ranges from 0-12, with zero reflecting the highest and 12 the lowest potential risks. Inv_file is determined by the PRS's assessment of the quality and enforcement standards of three different risk factors associated with foreign investments in the country, viz. (i) contract viability or risk of expropriation, (ii) payment delays, and (iii) repatriation of profits. Each subcomponent is scored on a scale of 0-4 with zero being the highest risk and four reflecting a very low risk. Increase in the ratings suggests progress in the establishment and enforcement of regulations related to foreign investments. For ease of interpretation and comparability with other measures, we re-scale this index on scale of $0-100$.

\subsubsection{Strength of Investor Protection Index}

The third measure of IPS that we use is sourced from the World Bank Doing Business (WBDB) database, known as the Strength of Investor Protection Index (SIPI_WBDB), developed by Djankov et al. (2008) covering the period from 2006-2015. ${ }^{11}$ SIPI_WBDB captures the extent to which minority shareholders are protected against expropriation by corporate insiders, particularly against directors' misappropriation of a firm's assets for their own private benefit. The value of the index ranges from 0-10 with higher values signalling better corporate IPS. The index is constructed on the basis of information obtained from a survey of lawyers, judges, engineers, corporate and public officials in 190 countries. The computations are thus based on security related regulations, company laws, civil procedure

\footnotetext{
11 The database is only available from 2006.
} 
codes, and court rules of evidence. The index value ranging from 0-10 is estimated using a simple average of the percentile rankings of its three subcomponent indicators representing three different dimensions of corporate IPS, all measured on a scale of 0-10 rating.

The first of the three dimensions of SIPI_WBDB relates to the transparency of relatedparty transactions, referred to as the Extent of Disclosure Index (0-10). Higher rating designates greater transparency in related-party transactions executed by corporate insiders and signifies better IPS. The second dimension of SIPI_WBDB is based on directors' liability for self-dealing, termed as the Extent of Director Liability Index (0-10). Higher rating suggests a higher degree of rights granted to minority shareholders to account for directors/insiders being liable in the case of related-party transactions that may strip the firm's assets. It specifically captures the extent to which the minority shareholders have legal remedial courses to ensure that corporate insiders pay for damages caused to the firm, repay the profit claimed by the minority shareholders from successful transactions, fine and imprison in the case of theft, and directly sue directors for the damage the transactions may cause to the company. The third and final component of SIPI_WBDB is stated as Ease of Shareholder Suits Index (0-10) with higher values demonstrating greater powers accorded to shareholders to challenge the related-party transactions made by the insiders. It specifically reveals the extent to which shareholders have direct access to a company's internal documents and make use of the government inspectors without filing suits in court. It further reflects the degree to which documents and information are available to the plaintiff shareholder in the case of a legal trial. For further details on the methodology used in the construction of the SIPI_WBDB index and its components and subcomponents, refer to Djankov et al. (2008). For ease of comparison, we normalize the SIPI_WBDB factor on a scale of 0-100. 


\subsubsection{Country-level Institutional Measure of IPS}

Finally, the fourth alternative measure of IPS we use is a country level institutional quality indicator (ALT_WBGI) constructed by Kaufmann et al. (2010) and maintained by the World Governance Indicators (WGI) database of the World Bank. WGI produces six country level composite ratings/indicators, each reflecting broad dimensions of institutional quality and observance. These indicators are rated from 0-100 with 100 being the least risky and zero the most risky. The six indexes include Voice and Accountability, Political Stability and Absence of Violence/Terrorism, Government Effectiveness, Regulatory Quality, Rule of Law, and Control of Corruption. Although other institutional measures of IPS are available, such as from International Country Risk Guide (ICRG), Economic Intelligence Unit etc., the WGI are averaged ratings based on several hundred variables sourced from 31 different data sources. ${ }^{12}$ Governance indicators from several sources serve as perfect proxies as they cover much larger concepts of institutional quality. Kaufmann et al. (2010) demonstrate that using the composite measures based on averaged information from a vast number of sources significantly lowers the degree of measurement error relative to other IPS indicators available from individual sources.

For the purpose of this study we employ the four most relevant governance indicators capturing the standard and practice of the quality of the investor protection environment in different countries, i.e. Government effectiveness, Control of corruption, Regulatory quality and Rule of law. Following Brunetti and Weder (2003), the IPS measures we use in the study are continuous variables by virtue of averaging three years of an ordered variable which takes values ranging from 0-100. The underlying information from 31 different sources includes governance perceptions reported by survey respondents, non-governmental organizations, commercial business information providers, and public sector organizations worldwide. For

\footnotetext{
${ }^{12}$ Please refer appendix A for the different information sources used by WGI.
} 
detailed methodology on the construction, refer to Kaufmann et al. (2010). The WGI dataset is widely used in existing studies, primarily in investigating cross-country governance and the association between governance and growth (see, Kaufmann and Kraay, 2003).

\subsection{Measures of Home and Foreign Biases}

We employ two datasets to measure home and foreign biases exhibited by equity portfolio investors. First, the standard aggregate cross-country dataset of equity portfolio holding (in USD millions) is obtained from the Coordinated Portfolio Investment Survey (CPIS) of the International Monetary Fund (IMF). The CPIS gathers data on stocks of crossborder holdings of equities for 76 participating countries. ${ }^{13}$ We use the annual cross-country portfolio holdings data for the period 2001-2015 to construct measures of equity home bias $\left(C P I S \_H B\right)$ and equity foreign bias $\left(C P I S \_F B\right)$ as described below. Dictated by the availability of the data, 44 out of the 45 countries listed in the highly investable MSCI All Country Index are included in our analysis.

Second, we employ distinctive fund level country allocation data from Emerging Portfolio Fund Research (EPFR) to construct the foreign bias $\left(G F \_F B\right)$ manifested by global fund managers ${ }^{14}$. EPFR avails asset allocation data on traditional and alternative funds domiciled globally. These global funds are managed by world's largest and most sophisticated investment companies such as Blackrock, Templeton, Morgan Stanley etc. The sole purpose of these funds is to have optimal global allocations across all the investable global assets. We use the annual average (using monthly allocations) country allocations of 122 global equity funds for the period from 2001-2015. The size of all funds when combined is approximately

\footnotetext{
${ }^{13}$ For detailed descriptions of this dataset see Bekaert and Wang (2010).

${ }^{14}$ Given the granularity of the EPFR database, it has been employed by several studies (see Gelos and Wei, 2005; and Jotikasthira et al., 2012). However, as the funds are domiciled only in 13 countries, we are unable to construct efficient measures of home bias due to the smaller number of observations for our empirical analysis.
} 
US $\$ 120$ billion and is domiciled across nine countries. As these are global funds with the sole purpose of global allocations, we expect the foreign bias to be lower compared to the CPIS aggregate data which include various types of funds (undisclosed) and different investment styles.

Finally, for the benchmark we employ the total country level market capitalization figures of S\&P/IFC from the World Development Indicator (WDI) of the World Bank Further, we also use the MSCI investible market capitalization to construct the free float benchmark. We describe the measures of home and foreign biases in the sub-sections immediately below.

\subsubsection{Equity Home Bias}

Equity home bias $(E H B)$ refers to the degree to which domestic investors over-allocate their investable funds to the domestic equity market relative to the international capital asset pricing model (ICAPM) benchmark. Following Chan et al. (2005) we define equity home bias as in equation (1).

$$
E H B_{j t}=\log \left(\frac{W_{j j t}}{W_{j t}^{*}}\right)
$$

In equation (1) $W_{j j t}$ (defined in equation 2) represents domestic investors' weightings in the domestic market capitalization of country $j$ at time $t$.

$$
W_{j j t}=\frac{h_{j j t}}{T P H_{j t}}
$$

$h_{j j t}$ is the stockholdings of investors in their home market $j$ and $T P H_{j t}$ is the total portfolio holdings (domestic and foreign) of all investors domiciled in country $j$ at time $t$. CPIS reports the bilateral foreign equity portfolio holdings, with no investments in the domestic market, for each host country $j$. Following Fidora et al. (2007) we construct domestic holdings $\left(h_{j j t}\right)$ and total portfolio holdings of domestic investors $\left(\mathrm{TPH}_{j t}\right)$ as in equation (3). 


$$
h_{j j t}=\operatorname{MCap}_{j t}-\sum_{i=1}^{43} F P H_{i j t,} \quad i \neq j
$$

In equation (3) $M C a p_{j t}$ is the domestic market capitalization of country $j$ at time $t$ and $F P H_{i j t, i \neq j}$ is the equity holding in country $j$ by foreign investors domiciled in country $i$. Thus, $\mathrm{TPH}_{j t}$ is defined as in equation (4)

$$
T P H_{j t}=h_{j j t}+\sum_{k=1}^{43} F P H_{j i t, j \neq i}
$$

$\mathrm{FPH}_{j i t}$ is foreign securities (i) held by investors domiciled in country $j$ at time $t . W_{j t}^{*}$ is the ICAPM world benchmark allocation for country $j$ for the time $t$, which is the same for all investors in all countries and is defined in equation (5).

$$
W_{j t}^{*}=\frac{M C a p_{j t}}{\sum_{j=1}^{44} M C a p_{j t}}
$$

A zero value of $E H B_{j t}$ in Equation (1) indicates that portfolio investors do not manifest any bias towards their home market relative to the ICAPM benchmark, while a positive value indicates the presence of home bias. As the $E H B_{j t}$ is constructed using CPIS data, we denote it by $C P I S \_H B$ in further analysis.

\subsubsection{Equity Foreign Bias}

Relative to the suggestion of ICAPM, equity foreign bias implies a disproportionate investment of investors domiciled in country $i$ on the securities of firms based in country $j$. Mishra (2015) and Cooper et al. (2017) provide alternative methods in calculating equity home and foreign bias. Cooper et al. (2017) particularly highlight problems associated with the logratio scale measure which has been used in previous studies (see Chan et al., 2005; Lau et al., 2010). Following existing studies, the equity foreign bias measure using the freely floated market capitalization adjusted method is shown in equation 6 (see Cooper et al., 2017; Dahlquist et al., 2003; Kho et al., 2009; Mishra and Ratti, 2013). 


$$
E F B_{i j t}=W_{i j t}-F W_{j t}^{*}
$$

where $W_{i j t}$ (defined in equation 7) is the investment allocation of investors domiciled in country $i$ on equities issued by firms based in country $j$ at time $t$.

$$
W_{i j t}=\frac{h_{i j t}}{\sum_{j=1}^{44} h_{i j t}} \quad i \neq j
$$

In equations (7) $h_{i j t}$ denotes country $i$ 's investors' equity holdings in country $j$ at time $t$. All the 44 countries in our sample data received foreign equity investment, so $h_{i j t} \neq 0$. $W_{i j t}$ is constructed using the cross-country holding data of CPIS and the EPFR data directly provides the weightings. Hence, there are two proxies of foreign bias.

$F W_{j t}^{*}$ (in equation 8) is the ICAPM free float or investible benchmark allocation for country $j$ for time $t$ and is defined in equation (8).

$$
F W_{j t}^{*}=\frac{F M C a p_{j t}}{\sum_{j=1}^{44} F M C a p_{j t}}
$$

FMCap $_{j t}$ is the free float domestic market capitalization of country $j$ at time $t$ available to foreign investors $i$. We calculate $F W_{j t}^{*}$ using a country's free float market capitalization available to all investors ${ }^{15}$. The use of free float market capitalization helps us to avoid scaling and transforming issues that could be encountered when using log-ratio in the construction of foreign bias.

Following Bekaert and Wang (2009) we normalized equity foreign bias measure to ensure that the values lie between -1 and 1 as presented in Equation 9 and 10 .

$$
\begin{gathered}
\frac{F W_{j t}^{*}-W_{i j t}}{F W_{j t}^{*}-0} \text { When } W_{i j t} \leq F W_{j t}^{*}(\text { underinvestment }) \\
-\left(\frac{W_{i j t}-F W_{j t}^{*}}{1-F W_{j t}^{*}}\right) \text { When } W_{i j t}>F W_{j t}^{*}(\text { overinvestment })
\end{gathered}
$$

\footnotetext{
${ }^{15}$ We use MSCI investable market capitalization that is available to all investors, thus avoiding scaling issues in the construction of foreign bias, as in some countries not all equities are freely floated for investments by foreign investors (see Dahlquist et al., 2003).
} 
In extreme cases, $E F B_{i j t}$ is 1 if investors domiciled in country $i$ hold no equities issued by firms based in country $j$ and -1 if investors domiciled in country $i$ invest all equities issued by firms based in country $j$ except for its own equities. In our analysis we take the rescaled value of the average equity foreign bias $\left(A E F B_{j t}\right)$ exhibited by all source country investors $(i=1 \ldots . . n)$ for country $j$ for each time $t$ as shown in equation (11).

$$
1-A E F B_{j t}=\sum_{i=1}^{n} E F B \quad i \neq j
$$

We rescale $A E F B_{j t}$ to $1-A E F B_{j t}$ for the sake of comparability and accessible interpretation. This now indicates that value of one is no foreign bias, value greater than one higher investments relative to the benchmark and value less than one lower investments relative to the benchmark. Thus, we should now expect positive relationship between foreign bias and investor protection measures. In subsequent analysis the measure of foreign bias based on CPIS-IMF data is referred to as CPIS_FB and the measure based on EPFR Global Funds' data is denoted by $G F_{-} F B$.

\subsection{Control Variables}

We control for a number of factors that are likely to drive the quality of investor protection standard for a given country. These include previous year's market return (Retn_l), market capitalization to GDP ratio $(M G D P)$, turnover ratio (Turn), inflation rate (Infl), trade openness (LSMI), valuation effect (Tobinq), press freedom (Press), political stability (PolStab), and GDP per capita $(G D P P C)$. Brief justification for each control variable is discussed below.

First, Hermalin and Weisbach (1988) argue that governance depends on past firm performance, which if persistent, implies that governance and firm performance are linked endogenously via their common dependence on past firm performance. To account for such an effect we include one year lagged stock returns (Retn_l). Retn_l is calculated as the previous 
year's average of monthly returns using MSCI total return index. Second, Rajan and Zingales (1998) show that financial development is positively related to the standard of investor protection. We account the role of financial development by using the ratio of equity market capitalization to GDP $(M G D P)$ reflecting the level of stock market development relative to the size of the economy. Third, we incorporate the effect of market liquidity by including the turnover ratio (TURN) defined as the ratio of total value of stocks traded to market capitalization. We obtain both the stock market development data from WDI.

Fourth, we control for inflation (Infl) to ensure that our analysis is not driven by variations in macroeconomic reforms which may further drive regulatory reforms. We expect inflation to be negatively associated with IPS. Annual inflation rates of each country are sourced from WDI.

Fifth, Rajan and Zingales (2003) also provide both theoretical and empirical evidence confirming the association between trade openness and institutional development. ${ }^{16}$ To capture the effects of trade openness and integration on investor protection, we include the log values of a country's exports and imports scaled by GDP (LSMI) as a control variable. Data required to estimate trade openness are obtained from WDI.

Sixth, we employ Tobinq to capture the effect of valuation on investor protection. It is conceivable that countries enjoying higher stock market valuations have a good governance system, which reduces the risk and cost of capital. La Porta et al. (2002) provide evidence of a positive association between higher valuations of firms and strong investor protection. The country level Tobinq measure is constructed by taking the ratio of each country's constituent firms' total liabilities plus equity market value to the book values of the firms' assets.

We employ a press freedom (Press) index controlling the influence of free media and free access to information on the development of investor protection standard. Busse and

\footnotetext{
${ }^{16}$ Also, see Laffont and N'Guessan (1999) for the impact of trade openness on corruption.
} 
Gröning (2008) show that countries that allow adequate press freedom have better investor protection and less corruption. A free media with access to information enhances checks and balances on both companies and government activities. Press freedom index takes a value of 0 (lowest degree of press freedom) and 100 (highest degree of press freedom). We expect press freedom to be positively associated with investor protection. We obtain data on press freedom from WGI and use the subcomponents of voice and accountability.

A measure of political stability (PolStab) is used to capture the level of stability in a country. Countries that are politically stable and free from internal/external conflicts are expected to have institutions that can enhance the quality of governance and provide better investor protection. We use PolStab to capture the effect of a stable government on investor protection. We obtained the political stability rating index (0-100) from WGI, the higher value of the index reflecting higher stability. Finally, countries that have a high income level have enough financial resources to establish strong institutions and hold government accountable to provide better investor protection. As such, following Bris and Cabolis (2004) we use GDP per capita $(G D P P C)$ to capture the effect of wealth and economic development on IPS. The data are obtained from WDI.

\section{Empirical Analysis}

In this section we report and discuss the results of empirical estimations testing the proposition: whether varying degrees of home and foreign biases in international equity portfolio allocations influence the quality IPS. We begin with a brief examination of the crosscountry summary analysis of key variables, followed by a discussion of multivariate regression estimations. 


\subsection{Cross-sectional Summary}

Our sample includes 23 developed and 21 emerging markets, as classified by MSCI, for the period from $2001-2015^{17}$. Table 1 reports the overall average values of the key variables of each country. As seen and expected, the figures of Panel A (columns 2-5) show that developed markets tend to exhibit a higher quality of IPS relative to emerging markets. For example, against the firm-level governance (Firm_Gov) measure, Canada ranks topmost among the top ranked countries, followed by the United States, Switzerland, Finland, Ireland, the Netherlands, Australia, Israel, New Zealand and France. However, countries that rank in the bottom 10 are generally emerging markets: Egypt, Indonesia, the Philippines, Romania, Brazil, Russia, Turkey, South Africa, China and Argentina. A similar pattern is observed in the other measures of IPS. The statistics in panel B show that the average quality of IPS (all four measures) is significantly higher for developed markets compared to their emerging markets' counterpart.

\section{.Insert Table 1 about here}

The average figures of home bias i.e. CPIS_HB, (Panel A, column 6) show that the top ten countries with the lowest home bias are mostly developed countries (except China) with the United States being number one (least biased) followed by the United Kingdom, Japan, the Netherlands, Germany, France, Ireland, Canada, and Italy. Similarly to the case of IPS, countries that display the highest degree of home bias are predominantly emerging markets, led by Bulgaria, Romania, Hungary, Peru, the Czech Republic, the Philippines, Egypt, Argentina, Poland, and Indonesia. The MSCI investable used foreign bias, figures (i.e. CPIS_FB, column 7) illustrate that the developed countries generally occupy the top ten positions. These countries include Ireland, Germany, France, Netherlands, Italy, Japan,

\footnotetext{
${ }^{17}$ IPS data cover the following periods: Firm_Gov 2003-2008, SIPI_WBDB 2006-2015; Inv_file and ALT_WBGI 2001-2015.
} 
Belgium, Austria, Hong Kong, and United Kingdom. Generally, developed countries are preferred by international investors compared to emerging markets. $G F_{-} F B$, a measure of foreign bias exhibited by the global funds, also suggests a similar pattern (column 8). Although the global funds are expected to be managed by the most sophisticated managers and hold globally diversified portfolios, the data reveal foreign biases in their investments.

The univariate anecdotal evidence presented above suggests that countries that have investors manifesting lower home bias and attracting more foreign investors are associated with better standards of investor protection. This is also reflected in the analysis when all the countries are grouped into developed and emerging markets. Panel B (Table 1) shows that the differences in all three measures of biases (i.e. $C P I S \_H B, C P I S \_F B$ and $G F \_F B$ ) between the developed and emerging markets are statistically significant, indicating that the developed countries experience lower home and higher foreign biases respectively. ${ }^{18}$ The estimates reported in Panel C (Table 1) further support the conjecture that higher (lower) home (foreign) bias may be negatively related to the quality of IPS. The difference in average home bias $\left(C P I S \_H B\right)$ of the top and bottom ten countries, as two different groups, is -4.30 . Similarly, both measures of foreign biases also indicate substantial differences between the two groups. The differences in all four measures of IPS also reveal similar patterns, indicating that the countries with lower (higher) home (foreign) biases are characterised by better IPS.

The country level average values of control variables, presented in Table 2, demonstrate that developed markets, relative to emerging markets, have a lower historical return (Ret_l), higher liquidity \& higher turnover ratio (Turn), more developed stock markets (MGDP), better integration with world economy (LSMI), higher stock market valuation (Tobinq), better

${ }^{18} C P I S \_H B(3.38-5.88=-2.5), C P I S \_F B(1.0031-0.9967=0.0064)$ and $G F \_F B(1.0083-0.9859=0.0024)$. All differences are statistically significant at $5 \%$. 
political stability (PolStab) with lower risk of potential internal and external conflict, and greater independence of press freedom (Press).

\section{Insert Table 2 about here}

\subsection{Bivariate Correlation Analysis}

Table 3 reports the correlation coefficient matrix between all the variables employed in our analysis. Consistent with expectations, the equity home bias measure is negatively correlated with all the four measures of IPS. This suggests that countries that experience overinvestment in the local stock market by domestic investors are associated with experiencing poor IPS. Similarly, the two foreign bias measures are positively correlated with the IPS measures, which imply that a higher presence of foreign investors is positively related to higher IPS in the host countries. With regard to the control variables, most of them carry expected signs.

\section{...............Insert Table 3 about here..............}

\subsection{Multivariate Regression}

The cross-country summary and correlation analyses discussed in the previous section signify that countries that are characterised with lower home bias seems to be associated with superior IPS. However, whether cross-sectional and temporal variations in home and foreign biases exhibited by equity portfolio investors, in part, may explain the differences in crosscountry IPS, after accounting for the possible factors, remains to be tested. In this section we address this by using country level panel data regressions controlling for country and year fixed

effects. We run the regressions using first difference $\triangle I P S_{j t}$ and $\triangle S P A_{j t}$ to mitigate the potential issues of any trend/non-stationarity concerns. More specifically, the following general specification (12) is estimated.

$$
\Delta I P S_{j t}=\alpha+\beta_{1} . \Delta S P A_{j t}+\beta_{2} \cdot \Delta C t l_{j t}+\beta_{3} . T F E_{t}+\beta_{4} . C F E_{j}+\epsilon_{j t}
$$


In equation (12) $\triangle I P S_{j t}$ represents the first difference of one of the four measures of $\triangle I P S_{j t}$ (i.e. Firm_Gov, Inv_file, SIPI_WBDB, and $A L T \_W B G I$ ), one at a time, of country $j$ at time $t$. $S P A$ is a vector of estimates of suboptimal portfolio allocations (i.e. biases in investors' portfolios: $C P I S \_H B, C P I S \_F B$ and $\left.G F \_F B\right)$, regressed one at a time. $C t l_{j t}$ is a vector of the control variables of country $j$ at time $t$. TFE and $C F E$ are time (year) and country fixed effects respectively. ${ }^{19}$ Throughout the analysis, all coefficients are estimated based on double clustered standard errors, the clustering done at the country and year level (Petersen, 2009). All the coefficients are reported as partial elasticity and the $t$-statistics are reported in parenthesis. As there are three different measures of SPA and four factors of IPS, we run three set of regressions (reported in Tables 4-6), estimating four equations (one for each measure of IPS).

\subsubsection{Investor Protection Standards and Equity Home Bias}

This section discusses the regression results of the effect of home bias $\left(C P I S \_H B\right)$ on the four different measures of IPS (one at a time) as shown in equation (13). The key explanatory variable of interest in all four specifications (one for each measure of IPS) is home bias $\left(C P I S \_H B\right)$ of country $j$ in year $t$.

$$
\Delta I P S_{j t}=\alpha+\beta_{1} \cdot \Delta C P I S_{-} H B_{j t}+\beta_{2} . \Delta C t l s_{j t}+\beta_{3} . T F E_{t}+\beta_{4} \cdot C F E_{j}+\epsilon_{j t}
$$

The results of the four regressions (one for each measure of IPS) are reported in Table 4. As evident throughout the four specifications (models 1- 4), the coefficients of CPIS_HB enter the regressions with the expected negative sign and are statistically significant. This evidence offers a strong indication of the view that home bias (i.e. the over allocation of portfolio investment in local stock markets) is negatively related to the quality of IPS of a country. These results are consistent with the theoretical assumption of Errunza (2001) who

\footnotetext{
${ }^{19}$ For the sake of brevity we do not report the estimates of year and country fixed effects.
} 
conjectures that the manifestation of higher home bias restricts foreign investors' presence which, in turn, prevents the possibility of foreign investors exporting good IPS practices to the host country.

\section{Insert Table 4 about here}

In terms of economic implications, the coefficients indicate ${ }^{20}$ that ceteris paribus, a one percentage decrease in home bias measure, on average, increases the Firm_Gov by $0.37 \%$ (model 1), Inv_file by $0.50 \%$ (model 2), SIPI_WBDB by $0.55 \%$ (model 3), and ALT_WBGI by $0.58 \%$ (model 4 ). The goodness of fit measure (adjusted $\mathrm{R}^{2}$ ) reported for all four models ranges from $46 \%-57 \%$, suggesting a good statistical fit of all the four specifications. These results provide strong support to our hypothesis, i.e. a reduction in home bias observed by domestic investors may lead to improvement in the quality of IPS. As noted earlier these effects may take place through the influence of foreign investors' monitoring effects, and these seeming associations are consistent with the predictions of existing literature (see Errunza, 2001; Huang and Zhu, 2015; Rajan and Zingales, 2000; Stulz, 2005).

\subsubsection{Investor Protection Standards and Empirical Foreign Bias}

Next, we replace the home bias measures with the proxy of foreign bias, as specified in equation (14). In this set of analyses the key explanatory variable of interest is a measure of foreign bias $\left(C P I S_{-} F B_{j t}\right)$ of country $j$ in year $t$. The specifications also include all control variables, time fixed effects $\left(T F E_{t}\right)$ and country fixed effects $\left(C F E_{j}\right)$. The estimates of all four specifications are reported in Table 5.

\footnotetext{
${ }^{20}$ As with any observational empirical investigation, all our estimates in this study are also based on the regular assumption of exogeneity and limited to the sample period we use. Thus, economic interpretation needs to be exercised with due caution. Despite the fact that it is very challenging to fully mitigate the issue of endogeneity, our study does provide strong evidence of the relationship. However, we undertake robustness checks to address endogeneity later in this section.
} 


$$
\Delta I P S_{j t}=\alpha+\beta_{1} \cdot \Delta C P I S_{-} F B_{j t}+\beta_{2} \cdot \Delta C t l s_{j t}+\beta_{3} \cdot T F E_{t}+\beta_{4} \cdot C F E_{j}+\epsilon_{j t}
$$

Consistent with the economic justifications developed earlier, the estimated coefficient of $C P I S \_F B$ is positive and statistically significant in all the four models. The coefficient of 0.379 CPIS_FB in model (1) of Table 5 suggests a positive association between the firm-level governance of a country and portfolio allocation of foreign investors. Similarly, models 2, 3 and 4 also exhibit the positive effect of $C P I S \_F B$ on measures of IPS. These results offer strong support to the economic conjecture that countries that attract higher level foreign equity portfolio investments, relative to the implied benchmark, are associated with higher levels of corporate governance and regulatory quality, i.e. superior IPS. The findings are also consistent with the implications of the literature discussed earlier (see Errunza, 2001; Stulz, 2005).

\section{Insert Table 5 about here}

\subsubsection{Investor Protection Standards and Global Fund Foreign Bias}

Table 6 reports the estimates of Equation (15) in which the key variable of interest is $G F \_F B$, a measure of foreign bias in the portfolio of global equity funds of EPFR. As in earlier specifications, all control variables discussed are incorporated, including year effects $\left(T F E_{t}\right)$, and country fixed effects $\left(C F E_{j}\right)$ are also controlled for.

$$
\Delta I P S_{J t}=\alpha+\beta_{1} \cdot \Delta G F_{-} F B_{j t}+\beta_{2} \cdot \Delta C t l s_{j t}+\beta_{3} . T F E_{t}+\beta_{4} \cdot C F E_{j}+\epsilon_{j t}
$$

Similarly to the results reported in Table 5, the expected positive and statistical significance of the coefficient of $G F_{-} F B$ (in all four models) implies that the biases observed, even in the international portfolio allocation of global funds, also have important implications for the IPS of host countries. These findings are consistent with the economic justification of 
Errunza (2001) who notes that foreign investors from well governed countries ${ }^{21}$ not only demand better governance but also export good governance from the source countries.

\section{[..............Insert Table 6 about here..............}

Overall, the results discussed in Tables 4-6 confirm the views that the presence of foreign investors can help improve the quality and standard of investor protection in host countries. Consequently, countries with higher home bias suffer from poor governance quality. On the other hand, countries that are favoured by foreign investors experience improvements in the quality of IPS.

\subsubsection{Results of Control Variables}

The coefficients of control variables reported in Tables 4-6 generally bear the expected signs and are statistically significant. Turn, LMSI, Tobinq, and GDPPC are positive and statistically significant. These results are consistent with the findings reported in existing studies (see, for example, La Porta et al., 2002; Lau et al., 2010; Rajan and Zingales, 2003). Infl is inversely related to investor protection and is generally statistically significant across the specifications. Similarly, PolStab, and Press are positively associated with investor protection but their statistical significance levels are sensitive to alternative specifications. The coefficients of other control variables, such as lagged return (Retn_l) and stock market development $(M G D P)$, are also dependent on the specification of equations, suggesting that they lack a systematic effect on IPS. Not surprisingly, such instability in the role of control variables is also reported by earlier studies such as Lau et al. (2010) and Gelos and Wei (2005).

\footnotetext{
${ }^{21}$ The countries included are: the United States, the United Kingdom, Canada, Germany, France, Denmark, Switzerland, Luxembourg, Finland, Singapore, Norway, Australia and Austria.
} 


\subsection{Robustness Checks}

The results discussed above provide strong evidence that suboptimal international portfolio allocations, i.e. home and foreign biases, seem to have implications for a country's IPS. In this section we present additional tests to validate the robustness of empirical results. We also address the concern of endogeneity (particularly reverse causality) by examining the relation between IPS and international portfolio allocation using a dynamic Generalized Method of Moments (GMM) panel estimation and an exogenous shock based method linked to the recent 2010 European sovereign debt crisis. The results are reported in Table $7 .^{22}$

\section{.Insert Table 7 about here}

\subsubsection{Dynamic GMM Estimation}

Although the incorporation of lagged explanatory variables may mitigate the concerns of endogeneity to a certain extent, it may not be enough. We further address this issue by employing the dynamic GMM estimation. Following Hoechle et al. (2012) and Wintoki et al. (2012) we include the first difference of IPS as an internally generated instrumental variable to estimate the first difference dynamic GMM regression (see Arellano and Bover, 1995, for further details of the method). The dynamic GMM estimation is suitable when the time span is smaller and the cross-section of observations is larger. Since our panel dataset includes 15 years of annual observations (time series) for 44 sample countries (cross-section) the dynamic GMM method is empirically appropriate. The model is specified in Equation (16):

$$
\Delta I P S_{j t}=a+\beta_{1} \Delta I P S_{j t-1}+\beta_{2} \Delta X_{j t-1}+\gamma \Delta Z_{j t-1}+\epsilon_{j t}
$$

where IPS is a measure of investor protection standards (one of the four measures of IPS is regressed at a time), $\Delta X_{j t-1}$ represents the instrumented suboptimal equity portfolio variables

\footnotetext{
${ }^{22}$ For brevity, we do not report the coefficients of control variables but these are available upon request.
} 
(i.e. a measure of bias in international portfolio allocation) and $Z_{j t-1}$ represents the control variables identified earlier.

Panel B (Table 7) reports the coefficients of $\Delta X_{j t-1}\left(\beta_{2}\right)$ and associated overidentification test results. The coefficients of home and foreign biases are statistically significant with expected signs in all specifications. Thus, the dynamic GMM estimation further adds support to the economic conjecture and our key findings discussed earlier that the prevalence of home bias in equity investors' portfolio deteriorates IPS in the home country whilst higher foreign bias plays a positive role in improving IPS.

\subsubsection{Shock Based Test}

We further employ a shock based quasi-experiment to separate the exogenous effects of suboptimal allocation by equity investors on IPS. We exploit the exogenous shock created by the 2010 Eurozone sovereign debt crisis that led to severe stress in the European markets, particularly for the Eurozone countries. De Grauwe and Ji (2013) show that the crisis affected some Eurozone countries more than others. For instance, in our sample five countries, i.e. Greece, Ireland, Italy, Portugal and Spain (GIIPS) suffered a greater decline in their stock markets compared to other euro (non-GIIPS) countries (Austria, Belgium, Finland, France, Germany and the Netherlands). Since size of the stock market is related to home and foreign bias measures, we observe the changes in the average measure of suboptimal equity allocations (i.e. home and foreign biases) for the GIIPS and non-GIIPS Eurozone countries.

In Figures 1 and 2 we plot the average CPIS based home and foreign bias measures for the GIIPS and for the rest of non-GIIPS Eurozone countries. The figures show that, since the onset of the crisis (2010) the level of home bias in GIIPS countries amplified significantly more than that in non-GIIPS Eurozone countries. In unison, foreign bias significantly diminished in the GIIPS countries compared to non-GIIPS Eurozone countries. Undoubtedly, the trends of 
home and foreign biases of the GIIPS and non-GIIPS Eurozone were varyingly but exogenously affected by the sovereign debt crisis. The pattern of home and foreign biases, with respect to the crisis of 2010, depicted in Figures 1 and 2, offers an ideal set-up to examine whether the differential changes caused by the exogenous crisis led to any causal implications on the level of IPS for GIIPS, relative to non-GIIPS Eurozone countries.

Insert Figure 1 about here

Insert Figure 2 about here

We use something similar to the difference-in-differences method to examine the effects of home and foreign biases on IPS. To this end we first generated a dummy variable $\left(G_{t}\right)$ that takes the value of one for the GIIPS countries (treated group), and zero for the non-GIIPS Eurozone countries (the control group). Second, a post-crisis year dummy ( Post $_{\text {crisis }}$ ) to represent the crisis shock from 2011 onwards is also created. Finally, an interactive variable $\left(\mathrm{G}_{\mathrm{t}} \times\right.$ Post $\left._{\mathrm{crisis}} \times S P A_{j t}\right)$ is generated and introduced in Equation (17).

$$
I P S_{j t}=a+\beta_{1} G_{t}+\beta_{2} \text { Post }_{c r i s i s}+\beta_{3}\left(G_{t} \times \text { Post }_{\text {crisis }} \times S P A_{j t-1}\right)+\beta_{4} \text { Controls }_{j t-1}+\epsilon_{j t}
$$

In specification (17) $I P S_{j t}$ is one of the four measures of IPS discussed earlier and the coefficient of interest is $\beta_{3}$. A statistically significant $\beta_{3}$, with expected sign (i.e. negative in the case of home bias and positive in the case of foreign bias) should provide a strong indication that changes in IPS of GIIPS and non-GIIPS Eurozone countries are differently affected by the exogenous changes in home and foreign biases driven by the 2010 European sovereign debt crisis.

The statistical significance and expected signs of $\beta_{3}$ coefficients for all four regressions, as reported in Table 7 (panel B), support the view that an increase in home bias seems to weaken a country's IPS. However, a rise in equity foreign bias has a positive impact on country level IPS. These shock based results offer a robust indication that suboptimal international 
diversifications by domestic and foreign investors have important implications for the development of IPS.

\section{Conclusions}

In spite of extensive evidence on what causes home and foreign biases in international equity portfolio allocation, studies investigating their implications are highly limited. Economic reasoning implies that financial globalization that promotes optimal international portfolio allocations should help improve the standard of investor protection in host countries. In a financially open economy domestic and foreign investors should hold optimum levels of equities compatible with the ICAPM benchmark. However, defying the normative suggestions equity investors exhibit different degrees of home and foreign bias in their international portfolio allocation.

This is the first study to empirically examine whether the widely documented home and foreign biases in international portfolio allocation have any implication for investor protection standards (IPS). We examine this issue by analysing a sample of 44 countries spanning 15 years. Consistent with economic justifications, the results suggest that biases in international portfolio allocation carry important implications for the development of IPS. We find that the markets characterised with a higher degree of home bias are associated with poor corporate and state IPS. Similarly, countries that allow for greater participation of foreign portfolio investors (i.e. greater foreign bias) have superior IPS. More specifically, our findings suggest that the quality of IPS in a country improves as domestic and foreign investors undertake optimal international equity portfolio investment. In summary, our findings support the economic conjecture that an optimal financial globalization, as prescribed by the ICAPM, can have a significant positive effect on the IPS of a country. 


\section{References}

Aggarwal, R., Erel, I., Ferreira, M. \& Matos, P. (2011). Does governance travel around the world? Evidence from institutional investors. Journal of Financial Economics 100, 154181.

Arellano, M. \& Bover, O. (1995). Another look at the instrumental variable estimation of errorcomponent models. Journal of Economics 68, 29-51.

Bekaert, G. \& Wang, X. (2010). Inflation risk and the inflation premium. Economic Policy 25, 755-806.

Bekaert, G., Harvey, C. R. \& Lundblad, C. (2007), Liquidity and expected returns: Lessons from emerging markets, Review of Financial Studies 20, 1783-1831.

Bonaglia, F., Macedo, J. B. \& Bussolo, M. (2001). How Globalization Improves Governance. Discussion Paper No. 2992. Paris, France: Centre for Economic Policy Research, Organisation for Economic Co-operation and Development.

Boubakri, N., Cosset, J.-C. \& Guedhami, O. (2005). Post-privatization corporate governance: The role of ownership structure and investor protection. Journal of Financial Economics 76, 369-399.

Bris, A. \& Cabolis, C, (2004). The Value of Investor Protection: Firm Evidence from CrossBorder Mergers. Yale ICF Working Paper No. 04-32, Yale International Centre for Finance.

Brunetti, A. Weder, B. (2003). A Free Press is Bad News for Corruption. Journal of Public Economics 87, 801-1824.

Busse, M. \& Gröning, S. (2009). Does Foreign Aid Improve Governance? Economics Letters 104(2), 76-78.

Chan, K., Covrig, V. \& Ng, L. (2005). What determines the domestic bias and foreign bias? Evidence from mutual fund equity allocations world- wide. Journal of Finance 60, 14951534.

Cooper, I. A., Sercu, P. \& Vanpée, R. (2015). Is equity home bias different from foreign bias? https://editorialexpress.com/cgibin/conference/download.cgi?db_name=AFA2016\&paper_id $=541$

Accessed 04.05.17.

Cooper, I. A., Sercu, P. \& Vanpée, R. (2017). A Measure of Pure Home Bias. Review Finance, rfx005, doi: 10.1093/rof/rfx005. 
Dahlquist, M., Pinkowitz, L., Stulz, R. M. \& Williamson, R. (2003). Corporate governance and home bias. Journal of Financial and Quantitative Analysis 38, 87.

De Grauwe, P. \& Ji, Y. (2013). Self-fulfilling Crises in the Eurozone: An empirical test. Journal of International Money and Finance 34, 15-36.

Djankov, S., La Porta, R., Lopez-de-Silanes, F. \& Shleifer, A. (2008). The law and economics of selfdealing. Journal of Financial Economics 88, 430-465.

Economist, (2008), German corporate governance: raising their voices. March 19.

Errunza, V. (2001). Foreign portfolio equity investments, financial liberalization, and economic development, Review of International Economics 9, 703-726.

Fidora, M., Fratzscher, M. \& Thimann, C. (2007). Home bias in global bond and equity markets: the role of real exchange rate volatility, Journal of International Money and Finance 26, 222-225.

Gelos, R. G. \& Wei, S. J. (2005). Transparency and international portfolio holdings. Journal of Finance 60, 2987-3020.

Henry, P. (2000). Stock market liberalization, economic reform, and emerging market equity prices. Journal of Finance 55, 529-564.

Hermalin, B. E. \& Weisbach, M. S., (1988). The determinants of composition. Rand Journal of Economics 19, 589-606.

Hoechle, D., Schmid, M., Walter, I. \& Yermack, D. (2012). How much of the diversification discount can be explained by poor corporate governance? Journal of Financial Economics $102,41-60$.

Huang, W. \& Zhu, T. (2015). Foreign institutional investors and corporate governance in emerging markets: Evidence from split share reform in China. Journal of Corporate Finance 32, 312-326.

International Monetary Fund (2005), World Economic Outlook (April), Chapter II.

Islam, R. \& Montenegro, C. E. (2002). What determines the quality of institutions? World Bank Policy Research Working Paper No 2764. World Bank, Washington, DC.

Janakiramanan, S. (1986). A Model of International Asset Pricing with a Constraint on the Foreign Equity Ownership. Journal of Finance 41, 897-914.

Jotikasthira, C., Lundblad, C. \& Ramadorai, T. (2012). Asset Fire Sales and Purchases and the International Transmission of Funding Shocks. Journal of Finance 67, 2015-2050.

Kang, J. K. \& Kim, J. M. (2010). Do foreign investors exhibit a corporate governance disadvantage \& quest; an information asymmetry perspective. Journal of International Business Studies 41, 1415-1438. 
Kaufmann, D. \& Kraay, A. (2003). Governance and growth: Causality which way? - Evidence for the world, in brief. Washington DC: World Bank.

Kaufmann, D., Kraay, A., Mastruzzi, M. (2010). The World Governance IndicatorsMethodology and Analytical issues, Washington DC: World Bank.

Kho, B. C., Stulz, R. M. \& Warnock, F. E. (2009). Financial globalization, governance, and the evolution of home bias, Journal of Accounting Research 47, 597-635.

Kose, M. A., Cardarelli, R. \& Elekdag, S. (2010). Capital inflows: Macroeconomic implications and policy responses. Economic System 34, 333-356.

Laffont, J. \& N'Guessan, T. (1999). Competition and corruption in an agency relationship. Journal of Development Economics 60, 271-295.

La Porta, R., Lopez-de-Silanes, F., Shleifer, A. \& Vishny, R. (1997). Legal Determinants of External Finance. Journal of Finance 52, 1131-1150.

La Porta, R., Lopez-de-Silanes, F., Shleifer, A., \& Vishny, R. (1999). The Quality of Government, Journal of Law, Economics, \& Organization 15, 222-279.

La Porta, R., Lopez-de-Silanes, F., \& Shleifer, A. (2002). Government Ownership of Banks. Journal of Finance 57, 265-301.

Lau, S. T., Ng, L. \& Zhang, B. (2010). The world price of home bias. Journal of Financial Economics 97, 191-217.

Mishra, A. V. (2015). Measures of equity home bias puzzle. Journal of Empirical Finance 34, 293-312.

Mishra, A. V. \& Ratti, R. A. (2013). Home bias and cross border taxation. Journal of International Money and Finance 32, 169-193.

Morey, M. Gottesman, A., Baker, E \& Godridge, B. (2009). Does Better Corporate Governance Result in HigherValuations in Emerging Markets? Another Examination Using a New Data Set" . Journal of Banking and Finance 33, 254-262.

Petersen, M. A. (2009). Estimating standard errors in finance panel data sets: Comparing approaches. Review of Financial Studies 22, 435-480.

Rajan, R. \& Zingales, L. (1998). Which Capitalism: Lessons from the Asian Crisis. Journal of Applied Corporate Finance 11, 40-48.

Rajan, R., Zingales, L. (2000). The Governance of the New Enterprise. In Xavier Vives, ed Corporate Governance; Theoretical and empirical perspectives, Cambridge: Cambridge University Press. 201-227.

Rajan, R. G. \& Zingales, L. (2003). The Great Reversals: The Politics of Financial Development in the Twentieth Century. Journal of Financial Economics 69, 5-50. 
Stulz, R. M. (2005). Limits of Financial Globalization. Journal of Finance 60, 1595-1638.

Wei, S. J. (2000). Local Corruption and Global Capital Flows. Brookings Papers on Economic Activity 2: 303-352.

Wintoki, M. B., Linck, J. S. \& Netter, J. (2012). Endogeneity and the dynamics of internal corporate governance. Journal of Financial Economics 105, 581-606. 


\section{Table 1}

\section{Country level averages of Key Variables of Interest}

This table presents the averages of the four measures of investor protection standards $\left(I P S_{j t}\right)$ and three measures of biases (home and foreign) in international equity portfolio investments for the sample period. Panel A reports the time series averages of each variable for each sample country; averages of developed versus emerging markets using Morgan Stanley Capital Investment classification are presented in Panel B; and averages of the top and bottom ten countries ranked by the CPIS-based measure of home bias $\left(C P I S \_H B\right)$ are presented in Panel C. Firm_Gov is firm-level corporate governance indexes (column 2); Inv_file is investment profile (column 3); SIPI_WBDB is strength of Investor Protection Index (column 4); and $A L T_{-} W B G I$ is an alternative country level investor protection measure from World Bank Governance Indicators (column 5). All IPS measures are on a scale of 0-100 with higher values indicating higher standards of investor protection and governance. CPIS_HB (column 6) measures equity home bias calculated as the log (natural) value of the share of domestic investors in their own country's stock market capitalization $(j)$ relative to the country's world market capitalization weight (column 6); CPIS_FB is the IMF-CPIS based equity foreign bias measure computed using the world-market-based free float adjusted method by subtracting the average of foreign allocations from foreign investors domiciled in country $i$ investing in equities of country $j(i \neq j)$ ) from the MSCI investable benchmark allocation for country $j$ (column 7), and $G F_{-} F B$ is also an equity foreign bias measure constructed using EPFR's micro global fund level data (column 8).

Panel A

\begin{tabular}{|c|c|c|c|c|c|c|c|}
\hline Col 1 & Col 2 & Col 3 & Col 4 & Col 5 & Col 6 & Col 7 & Col 8 \\
\hline Country & $\begin{array}{l}\text { Firm_Gov } \\
(0-100)\end{array}$ & $\begin{array}{l}\text { Inv_file } \\
(0-12)\end{array}$ & $\begin{array}{l}\text { SIPI_WBDB } \\
(0-10)\end{array}$ & $\begin{array}{l}\text { ALT_WBGI } \\
(0-100)\end{array}$ & CPIS_HB & CPIS_FB & GF_FB \\
\hline Argentina & 25.8 & 6.49 & 4.56 & 34.4 & 6.25 & 0.9996 & 0.9993 \\
\hline Australia & 51.4 & 10.14 & 5.72 & 95.1 & 3.78 & 1.0123 & 1.0024 \\
\hline Austria & 45.2 & 8.34 & 5.14 & 97.9 & 4.75 & 1.0162 & 1.0036 \\
\hline Belgium & 37.1 & 7.25 & 6.91 & 88.6 & 3.62 & 1.0213 & 1.0052 \\
\hline Brazil & 24.6 & 8.32 & 5.36 & 43.8 & 4.44 & 0.9992 & 0.9929 \\
\hline Bulgaria & 26.7 & 7.27 & 5.08 & 51.9 & 9.25 & 0.9998 & 0.9933 \\
\hline Canada & 71.1 & 7.51 & 8.23 & 95.2 & 3.16 & 1.0006 & 1.0028 \\
\hline Chile & 35.8 & 7.32 & 5.07 & 87.9 & 5.56 & 1.0004 & 0.9995 \\
\hline China & 25.6 & 6.61 & 4.86 & 41.5 & 3.32 & 0.9885 & 0.9922 \\
\hline Czech Rep & 37.5 & 7.32 & 5.04 & 76.2 & 6.97 & 1.0005 & 0.9964 \\
\hline Denmark & 44.9 & 7.42 & 6.21 & 98.6 & 4.83 & 1.0007 & 1.0024 \\
\hline Egypt & 21.5 & 6.65 & 3.73 & 51.8 & 6.58 & 1.0002 & 0.9868 \\
\hline Finland & 53.3 & 8.69 & 5.68 & 99.5 & 4.96 & 1.0036 & 0.9993 \\
\hline France & 46.3 & 9.13 & 5.82 & 90.6 & 2.91 & 1.0464 & 1.0611 \\
\hline Germany & 45.7 & 7.63 & 5.1 & 93.2 & 2.88 & 1.0572 & 1.0704 \\
\hline Greece & 30.2 & 6.53 & 3.63 & 74.2 & 5.81 & 1.0027 & 0.9987 \\
\hline Hong Kong & 45.4 & 8.26 & 8.87 & 87.9 & 3.56 & 1.0147 & 1.0215 \\
\hline Hungary & 39.2 & 6.27 & 4.36 & 77.7 & 7.39 & 0.9996 & 0.9924 \\
\hline India & 28.3 & 7.2 & 4.92 & 56.9 & 4.39 & 0.9958 & 0.9917 \\
\hline Indonesia & 22.9 & 5.86 & 4.87 & 25.9 & 6.13 & 0.9984 & 0.9785 \\
\hline Ireland & 53.1 & 7.73 & 8.19 & 93.2 & 3.05 & 1.0586 & 1.0763 \\
\hline Israel & 49.4 & 8.18 & 8.17 & 78.5 & 5.79 & 1.0002 & 1.0015 \\
\hline Italy & 44.2 & 7.32 & 6.08 & 67.6 & 3.31 & 1.0281 & 1.0364 \\
\hline Japan & 41.6 & 7.34 & 6.92 & 88.4 & 2.35 & 1.0253 & 1.0549 \\
\hline Korea & 38.2 & 7.19 & 6.13 & 77.8 & 4.33 & 0.9874 & 0.9582 \\
\hline Malaysia & 25.8 & 7.33 & 5.63 & 64.3 & 5.36 & 0.9858 & 0.9724 \\
\hline Mexico & 34.5 & 7.24 & 5.44 & 39.7 & 5.23 & 0.9937 & 0.9816 \\
\hline Netherlands & 52.1 & 9.67 & 5.47 & 95.5 & 2.84 & 1.0414 & 1.0627 \\
\hline New Zealand & 48.8 & 8.52 & 9.33 & 97.2 & 6.05 & 1.0012 & 1.0006 \\
\hline
\end{tabular}




\begin{tabular}{llllllll} 
Norway & 43.7 & 8.98 & 6.73 & 99.1 & 4.41 & 1.0127 & 1.0214 \\
Peru & 27.2 & 5.61 & 5.28 & 30.7 & 7.05 & 0.9995 & 0.9848 \\
Philippines & 23.4 & 6.86 & 4.28 & 39.6 & 6.66 & 0.9998 & 0.9684 \\
Poland & 27.2 & 6.87 & 6.02 & 67.5 & 6.21 & 0.9991 & 0.9977 \\
Portugal & 37.8 & 8.05 & 5.99 & 85.3 & 5.96 & 1.0005 & 1.0047 \\
Romania & 23.4 & 6.39 & 4.98 & 52.1 & 7.98 & 0.9994 & 0.9754 \\
Russia & 24.7 & 6.28 & 4.74 & 20.4 & 4.61 & 0.9936 & 0.9765 \\
South Africa & 25.1 & 8.33 & 6.11 & 55.8 & 4.33 & 0.9947 & 0.9812 \\
Spain & 45.9 & 7.98 & 5.16 & 85.9 & 3.74 & 1.0012 & 1.0075 \\
Sweden & 46.2 & 10.74 & 5.81 & 97.7 & 3.98 & 1.0025 & 1.0192 \\
Switzerland & 54.7 & 10.14 & 6.35 & 97.8 & 3.37 & 1.0091 & 1.0312 \\
Thailand & 26.3 & 6.97 & 6.02 & 57.2 & 5.92 & 0.9977 & 0.9916 \\
Turkey & 24.8 & 5.98 & 5.54 & 54.1 & 5.86 & 0.9984 & 0.9943 \\
United Kingdom & 56.5 & 9.15 & 7.98 & 93.7 & 2.32 & 1.0138 & 1.0318 \\
United States & 61.7 & 7.92 & 8.11 & 91.8 & 0.79 & 0.7017 & 0.6748 \\
\hline
\end{tabular}

Panel B: Averages of the Developed and Emerging Markets

\begin{tabular}{llllllll}
\hline Economies & $\begin{array}{l}\text { Firm_Gov } \\
(0-100)\end{array}$ & $\begin{array}{l}\text { Inv_file } \\
(0-12)\end{array}$ & $\begin{array}{l}\text { SIPI_WBDB } \\
(0-10)\end{array}$ & $\begin{array}{l}\text { ALT_WBGI } \\
(0-100)\end{array}$ & CPIS_HB & CPIS_FB & GF_FB \\
\hline Developed & 48.1 & 8.37 & 6.59 & 90.95 & 3.38 & 1.0031 & 1.0083 \\
Emerging & 28 & 6.87 & 5.14 & 52.63 & 5.88 & 0.9967 & 0.9859 \\
Difference & 20.1 & 1.5 & 1.55 & 38.32 & -2.5 & 0.0064 & 0.0224 \\
\hline
\end{tabular}

Panel C: Averages of the Top and Bottom 10 Countries against CPIS_HB

\begin{tabular}{lllllrlc}
\hline Country & Firm_Gov & Inv_file & SIPI_WBDB & ALT_WBGI & CPIS_HB & CPIS_FB & GF_FB \\
\hline Top10 & 55.21 & 9.35 & 7.94 & 97.36 & 2.74 & 1.0315 & 1.0468 \\
Bottom10 & 24.18 & 6.27 & 4.49 & 37.90 & 7.04 & 0.9637 & 0.9452 \\
Difference & 31.03 & 3.08 & 3.45 & 59.46 & -4.30 & 0.0678 & 0.1016 \\
\hline
\end{tabular}


Table 2

Cross-Country Averages of Control Variables

This table reports the time series average of the control variables for each sample country: Retn_l is the average $M S C I$ index based total monthly return over the past year; Turn is the ratio of total value of stocks traded to market capitalization to market liquidity effects; MGDP is market capitalization scaled by GDP; Infl is the one year lagged rate of inflation based on the consumer price index; LSMI is market integration measured as the ratio of a country's annual exports plus imports divided by GDP; Tobinq is measured as the log (natural) book value of total liabilities plus market value of equity and divided by the book value of the corporate assets of country i; PolStab is the political stability measure ranging from 0-100 with higher rating indicating greater stability; Press is the press freedom indicator measure ranging from 0-100 with higher rating indicating greater freedom from government interference and $G D P P C$ is gross domestic product per capita.

\begin{tabular}{|c|c|c|c|c|c|c|c|c|c|}
\hline Country & Retn_1 (\%) & $\begin{array}{l}\text { Turn } \\
(\%)\end{array}$ & $\begin{array}{l}\text { MGDP } \\
(\% \text { of GDP) }\end{array}$ & $\operatorname{Infl}(\%)$ & $\begin{array}{l}\text { LSMI } \\
(\% \text { of GDP) }\end{array}$ & Tobinq & $\begin{array}{l}\text { PolStab } \\
(1-100)\end{array}$ & $\begin{array}{l}\text { Press } \\
(0-100)\end{array}$ & $\begin{array}{l}\text { GDPPC } \\
\text { (in USD) }\end{array}$ \\
\hline Argentina & 7.0 & 10.40 & 38.67 & 10.0 & 40.41 & 5.76 & 52.70 & 56.75 & 5918 \\
\hline Australia & 4.0 & 84.23 & 119.16 & 3.0 & 40.80 & 5.83 & 94.93 & 94.29 & 34705 \\
\hline Austria & 2.0 & 44.70 & 28.95 & 2.0 & 101.49 & 5.35 & 95.47 & 92.51 & 37845 \\
\hline Belgium & 1.0 & 44.74 & 65.83 & 3.0 & 153.17 & 5.09 & 93.37 & 93.04 & 36323 \\
\hline Brazil & 18.0 & 48.15 & 54.96 & 7.0 & 25.81 & 5.01 & 55.90 & 59.34 & 5834 \\
\hline Bulgaria & 9.0 & 18.62 & 17.52 & 5.0 & 116.48 & 5.25 & 58.07 & 64.43 & 4273 \\
\hline Canada & 3.0 & 75.43 & 114.47 & 2.0 & 70.33 & 5.67 & 96.49 & 96.02 & 35335 \\
\hline Chile & 13.0 & 15.37 & 107.11 & 4.0 & 69.21 & 0.21 & 85.34 & 78.11 & 8116 \\
\hline China & 9.0 & 122.53 & 69.07 & 3.0 & 58.66 & 4.18 & 57.24 & 6.96 & 2299 \\
\hline Czech Rep & 10.0 & 60.96 & 25.33 & 2.0 & 58.66 & 3.33 & 79.84 & 78.44 & 13843 \\
\hline Denmark & 1.0 & 81.36 & 63.31 & 2.0 & 124.87 & 3.72 & 99.62 & 98.75 & 47736 \\
\hline Egypt & 13.0 & 36.26 & 55.67 & 9.0 & 93.56 & 5.39 & 40.86 & 18.63 & 1639 \\
\hline Finland & 6.0 & 119.26 & 98.62 & 2.0 & 55.01 & 6.71 & 99.30 & 98.32 & 38092 \\
\hline France & 1.0 & 101.20 & 80.67 & 2.0 & 78.37 & 5.59 & 90.89 & 88.24 & 34014 \\
\hline Germany & 2.0 & 141.75 & 45.71 & 2.0 & 53.34 & 5.42 & 91.42 & 93.61 & 34333 \\
\hline Greece & 9.0 & 49.06 & 51.91 & 7.0 & 78.38 & 5.77 & 73.44 & 79.03 & 22032 \\
\hline Hong Kong & 1.0 & 77.91 & 421.17 & 2.0 & 362.90 & 3.69 & 93.90 & 58.75 & 27859 \\
\hline
\end{tabular}




\begin{tabular}{|c|c|c|c|c|c|c|c|c|c|}
\hline Hungary & 7.0 & 77.24 & 24.53 & 5.0 & 146.36 & 0.92 & 77.38 & 84.89 & 10655 \\
\hline India & 11.0 & 115.82 & 68.12 & 7.0 & 39.90 & 2.70 & 54.28 & 59.43 & 830 \\
\hline Indonesia & 8.0 & 53.16 & 30.03 & 8.0 & 56.92 & -1.81 & 44.54 & 39.16 & 1594 \\
\hline Ireland & 6.0 & 52.34 & 46.77 & 2.0 & 161.14 & 6.13 & 90.86 & 93.04 & 46103 \\
\hline Israel & 5.0 & 61.53 & 84.72 & 3.0 & 76.03 & 4.47 & 81.95 & 67.74 & 21799 \\
\hline Italy & 3.0 & 130.19 & 37.54 & 2.0 & 52.70 & 5.22 & 70.69 & 80.89 & 30279 \\
\hline Japan & 1.0 & 111.68 & 77.97 & 0.0 & 26.94 & 1.29 & 88.30 & 77.96 & 35857 \\
\hline Korea & 3.0 & 222.26 & 73.81 & 3.0 & 82.12 & -0.72 & 82.04 & 68.89 & 16657 \\
\hline Malaysia & 9.0 & 31.36 & 137.03 & 4.0 & 191.51 & 4.98 & 83.08 & 37.26 & 6036 \\
\hline Mexico & 4.0 & 27.84 & 28.33 & 4.0 & 54.33 & 4.11 & 61.19 & 53.14 & 7959 \\
\hline Netherlands & 1.0 & 147.38 & 91.33 & 2.0 & 132.82 & 6.12 & 96.07 & 98.32 & 39882 \\
\hline New Zealand & 10.0 & 46.31 & 36.38 & 2.0 & 59.34 & 6.22 & 94.54 & 98.08 & 25219 \\
\hline Norway & 4.0 & 114.81 & 55.67 & 2.0 & 71.45 & 4.41 & 96.50 & 98.13 & 66658 \\
\hline Peru & 6.0 & 12.97 & 47.15 & 2.0 & 43.06 & 5.17 & 40.95 & 47.33 & 3319 \\
\hline Philippines & 8.0 & 18.51 & 48.26 & 5.0 & 89.85 & 2.66 & 53.21 & 49.79 & 1428 \\
\hline Poland & 4.0 & 37.55 & 28.56 & 3.0 & 75.52 & 4.93 & 69.21 & 78.73 & 8802 \\
\hline Portugal & 3.0 & 63.47 & 39.39 & 9.0 & 67.27 & 5.02 & 82.15 & 90.93 & 18380 \\
\hline Romania & 7.0 & 12.97 & 16.31 & 11.0 & 75.08 & 3.49 & 49.77 & 60.20 & 5306 \\
\hline Russia & 6.0 & 58.94 & 61.59 & 10.0 & 55.18 & 2.66 & 41.83 & 28.67 & 6375 \\
\hline South Africa & 13.0 & 69.52 & 215.23 & 5.0 & 59.34 & 4.84 & 71.08 & 69.42 & 4868 \\
\hline Spain & 5.0 & 164.33 & 86.72 & 3.0 & 56.87 & 6.00 & 84.61 & 87.09 & 25992 \\
\hline Sweden & 4.0 & 121.81 & 104.08 & 4.0 & 89.37 & 3.48 & 97.84 & 97.98 & 41035 \\
\hline Switzerland & 3.0 & 99.91 & 229.24 & 1.0 & 88.85 & 5.21 & 97.95 & 96.83 & 54237 \\
\hline Thailand & 9.0 & 94.00 & 62.06 & 12.0 & 135.01 & 2.96 & 63.68 & 47.16 & 3021 \\
\hline Turkey & 14.0 & 152.80 & 28.94 & 9.0 & 49.15 & 5.26 & 61.92 & 41.72 & 6991 \\
\hline United Kingdom & 3.0 & 142.71 & 128.47 & 2.0 & 57.08 & 6.04 & 92.84 & 91.74 & 35933 \\
\hline United States & 2.0 & 212.34 & 124.09 & 2.0 & 25.46 & 6.50 & 90.47 & 88.50 & 42341 \\
\hline
\end{tabular}


Table 3

Pearson's pairwise correlation coefficient between the dependent and independent variables

Note: The variables labelled 1-4 are the four measures of investor protection standards $\left(I P S_{j t}\right)$ and 5-7 are the suboptimal international portfolio allocation bias measures. They are described in Table 1. The other variables include Retn_l which is the average MSCI index based on total monthly return over the past year; Turn is the ratio of total value of stocks traded to market capitalization to market liquidity effects; MGDP is market capitalization scaled by GDP; Infl is the one year lagged rate of inflation based on the consumer price index; LSMI is market integration measured as the ratio of a country's annual exports plus imports divided by GDP; Tobinq is measured as the log (natural) book value of total liabilities plus market value of equity and divided by the book value of corporate assets of country $i$; PolStab is the political stability measure ranging from 0-100 with higher rating indicating greater stability; Press is the press freedom indicator measure ranging from 0-100 with higher rating indicating greater freedom from government interference and GDPPC is gross domestic product per capita. For brevity and space, statistical significance of at least the $5 \%$ level is reported in bold.

\begin{tabular}{|c|c|c|c|c|c|c|c|c|c|c|c|c|c|c|c|c|}
\hline & 1 & 2 & 3 & 4 & 5 & 6 & 7 & 8 & 9 & 10 & 11 & 12 & 13 & 14 & 15 & 16 \\
\hline Firm_Gov (1) & 1 & & & & & & & & & & & & & & & \\
\hline Inv_file (2) & 0.36 & 1 & & & & & & & & & & & & & & \\
\hline SIPI_WBDB (3) & 0.44 & 0.43 & 1 & & & & & & & & & & & & & \\
\hline ALT_WBGI (4) & 0.27 & 0.31 & 0.23 & 1 & & & & & & & & & & & & \\
\hline CPIS_HB (5) & -0.23 & -0.36 & -0.43 & -0.42 & 1 & & & & & & & & & & & \\
\hline CPIS_FB (6) & 0.30 & 0.42 & 0.34 & 0.31 & -0.35 & 1 & & & & & & & & & & \\
\hline GF_FB (7) & 0.26 & 0.31 & 0.37 & 0.43 & -0.36 & 0.34 & 1 & & & & & & & & & \\
\hline Retn_1 (8) & 0.09 & 0.23 & 0.08 & 0.12 & 0.33 & -0.29 & -0.07 & 1 & & & & & & & & \\
\hline Turn (9) & 0.26 & 0.34 & 0.22 & 0.40 & -0.41 & -0.24 & $0 . .35$ & -0.36 & 1 & & & & & & & \\
\hline MGDP (10) & 0.10 & 0.17 & 0.12 & 0.08 & 0.26 & -0.21 & 0.15 & -0.20 & 0.11 & 1 & & & & & & \\
\hline Infl (11) & -0.25 & -0.10 & -0.39 & -0.06 & 0.28 & -0.26 & -0.08 & 0.20 & -0.16 & -0.12 & 1 & & & & & \\
\hline LSMI (12) & 0.19 & 0.14 & 0.20 & 0.31 & 0.15 & 0.30 & 0.24 & -0.05 & -0.03 & 0.31 & -0.14 & 1 & & & & \\
\hline Tobinq (13) & 0.11 & 0.28 & 0.31 & 0.10 & 0.22 & 0.19 & 0.24 & 0.05 & 0.03 & 0.11 & -0.17 & 0.08 & 1 & & & \\
\hline PolStab (14) & 0.10 & 0.13 & 0.08 & 0.18 & -0.06 & 0.04 & 0.12 & 0.02 & 0.04 & 0.04 & 0.17 & 0.10 & 0.08 & 1 & & \\
\hline Press (15) & 0.13 & 0.18 & 0.23 & 0.27 & -0.08 & 0.15 & 0.15 & 0.12 & 0.04 & 0.18 & -0.02 & 0.08 & 0.09 & 0.08 & 1 & \\
\hline GDPPC (16) & 0.17 & 0.28 & 0.22 & 0.06 & 0.21 & 0.43 & 0.42 & 0.21 & 0.42 & 0.24 & -0.32 & 0.16 & -0.34 & 0.10 & 0.05 & 1 \\
\hline
\end{tabular}


Table 4

Investor Protection Standards and CPIS based Equity Home Bias

$$
\Delta I P S_{j t}=\alpha+\beta_{1} . \Delta C P I S_{-} H B_{j t}+\beta_{2} . \Delta C t l_{j t}+\beta_{3} . T F E_{t}+\beta_{4} \cdot C F E_{j}+\epsilon_{j t}
$$

This table reports estimates of four specifications of Equation (13). In each specification the dependent variable is one of the four measures of investor protection (i.e. Firm_Gov, Inv file, SIPI_WBDB and $\left.A L T_{-} W B G I\right)$ as defined in the notes to Table 1 . The explanatory variable of key interest is $C P I S \_H B$, also defined in the notes to Table 1. All the control variables are defined in the notes to Table 2. All variables are used as first difference. The $t$-statistics, reported in parentheses, are based on double clustered standard errors (clustering done at the country and year levels). For tractable interpretation, all the coefficients are reported as elasticity and the statistical significance is reported against $10 \%(*)$, $5 \%(* *)$ and $1 \%(* * *)$ significance levels respectively.

\begin{tabular}{lcccc}
\hline & Model (1) & Model (2) & Model (3) & Model (4) \\
& Firm_Gov & Inv_file & SIPI_WBDB & ALT_WBGI \\
\hline$\Delta$ CPIS_HB & $-0.369^{* *}$ & $-0.503^{* *}$ & $-0.549^{* *}$ & $-0.581^{* * *}$ \\
& $(-2.17)$ & $(-2.26)$ & $(-2.42)$ & $(-3.73)$ \\
$\Delta$ Retn_1 & 0.323 & $0.684^{* *}$ & 0.372 & $0.348^{*}$ \\
& $(1.24)$ & $(2.38)$ & $(1.36)$ & $(1.71)$ \\
$\Delta$ Turn & $0.248^{* * *}$ & $0.256^{* * *}$ & $0.228^{* * *}$ & $0.325^{* * *}$ \\
& $(2.81)$ & $(3.59)$ & $(2.62)$ & $(4.22)$ \\
$\Delta$ MGDP & 0.684 & $0.775^{* *}$ & $0.762^{*}$ & 0.514 \\
& $(1.42)$ & $(2.05)$ & $(1.73)$ & $(1.02)$ \\
$\Delta$ Infl & $-0.477^{* *}$ & -0.364 & $-0.689 * * *$ & -0.326 \\
& $(-2.43)$ & $(-1.16)$ & $(-3.05)$ & $(-1.13)$ \\
$\Delta$ LSMI & $0.376^{* *}$ & $0.349^{*}$ & $0.507^{* * *}$ & $0.488^{* * *}$ \\
& $(2.27)$ & $(1.96)$ & $(2.63)$ & $(3.37)$ \\
$\Delta$ Tobinq & 0.223 & $0.482^{* *}$ & $0.556^{* * *}$ & 0.428 \\
& $(1.28)$ & $(2.17)$ & $(2.81)$ & $(1.35)$ \\
$\Delta$ PolStab & 0.226 & $0.330^{*}$ & 0.267 & $0.564 *$ \\
& $(1.42)$ & $(1.75)$ & $(1.23)$ & $(1.98)$ \\
$\Delta$ Press & $0.475^{* *}$ & $0.618^{* *}$ & $0.742^{* *}$ & $0.763^{* *}$ \\
& $(2.09)$ & $(2.26)$ & $(2.39)$ & $(2.47)$ \\
$\Delta$ GDPPC & $0.216^{* *}$ & $0.523^{* * *}$ & $0.475^{* *}$ & 0.139 \\
& $(2.35)$ & $(2.78)$ & $(2.43)$ & $(1.24)$ \\
Constant & $0.639^{* * *}$ & $0.817^{* * *}$ & $0.884^{* * *}$ & $0.289^{* * *}$ \\
& $(2.86)$ & $(4.37)$ & $(3.68)$ & $(2.52)$ \\
\hline Number of Observations & 264 & 616 & 440 & 616 \\
Adj. R-square & 0.46 & 0.57 & 0.49 & 0.52 \\
Country fixed effects & Yes & Yes & Yes & Yes \\
Year fixed effects & Yes & Yes & Yes & Yes \\
\hline
\end{tabular}


Table 5

Investor Protection Standards and CPIS based Equity Foreign Bias

$$
\Delta I P S_{j t}=\alpha+\beta_{1} . \Delta C P I S_{-} F B_{j t}+\beta_{2} . \Delta C t l s_{j t}+\beta_{3} . T F E_{t}+\beta_{4} . C F E_{j}+\epsilon_{j t}
$$

This table reports the estimates of four specifications of equation (14). In each specification the dependent variable is one of the four measures of investor protection (i.e. Firm_Gov, Inv_file, SIPI_WBDB and $A L T_{-} W B G I$ ) as defined in the notes to Table 1 . The explanatory variable of key interest is $C P I S \_F B$, also defined in the notes to Table 1 . All the control variables are defined in the notes to Table 2. All variables are used as first difference. The $t$-statistics, reported in parentheses, are based on double clustered standard errors (clustering done at the country and year levels). For tractable interpretation, all the coefficients are reported as elasticity and the statistical significance is reported against $10 \%(*), 5 \%(* *)$ and $1 \%(* * *)$ significance levels respectively.

\begin{tabular}{|c|c|c|c|c|}
\hline & $\begin{array}{l}\text { Model (1) } \\
\text { Firm_Gov }\end{array}$ & $\begin{array}{l}\text { Model (2) } \\
\text { Inv_file }\end{array}$ & $\begin{array}{c}\text { Model (3) } \\
\text { SIPI_WBDB }\end{array}$ & $\begin{array}{c}\text { Model (4) } \\
\text { ALT_WBGI }\end{array}$ \\
\hline$\Delta$ CPIS_FB & $\begin{array}{c}0.379 * * * \\
(2.69)\end{array}$ & $\begin{array}{c}0.534 * * * \\
(2.85)\end{array}$ & $\begin{array}{c}0.493 * * * \\
(2.48)\end{array}$ & $\begin{array}{c}0.597 * * * \\
(3.73)\end{array}$ \\
\hline$\Delta$ Retn_1 & $\begin{array}{l}0.488 \\
(1.33)\end{array}$ & $\begin{array}{c}0.744 * * * \\
(2.77)\end{array}$ & $\begin{array}{l}0.508 \\
(1.47)\end{array}$ & $\begin{array}{c}0.524^{*} \\
(1.75)\end{array}$ \\
\hline$\Delta$ Turn & $\begin{array}{c}0.263^{* *} \\
(2.16)\end{array}$ & $\begin{array}{c}0.374 * * * \\
(2.83)\end{array}$ & $\begin{array}{c}0.346^{* *} \\
(2.42)\end{array}$ & $\begin{array}{c}0.725 * * * \\
(3.11)\end{array}$ \\
\hline$\triangle \mathrm{MDGP}$ & $\begin{array}{l}0.549 \\
(1.05)\end{array}$ & $\begin{array}{c}0.721 * * \\
(2.28)\end{array}$ & $\begin{array}{c}0.693^{*} \\
(1.62)\end{array}$ & $\begin{array}{l}0.642 \\
(1.19)\end{array}$ \\
\hline$\Delta \operatorname{Infl}$ & $\begin{array}{c}-0.514 * * \\
(-2.32)\end{array}$ & $\begin{array}{l}-0.370 \\
(-1.36)\end{array}$ & $\begin{array}{c}-0.732 * * \\
(-2.44)\end{array}$ & $\begin{array}{l}-0.327 \\
(-1.28)\end{array}$ \\
\hline$\Delta \mathrm{LSMI}$ & $\begin{array}{c}0.457 * * \\
(2.18)\end{array}$ & $\begin{array}{c}0.348^{*} \\
(1.73)\end{array}$ & $\begin{array}{c}0.518 * * \\
(2.34)\end{array}$ & $\begin{array}{c}0.537 * * * \\
(2.92)\end{array}$ \\
\hline$\Delta$ Tobinq & $\begin{array}{l}0.377 \\
(1.26)\end{array}$ & $\begin{array}{c}0.672 * * * \\
(2.93)\end{array}$ & $\begin{array}{c}0.686 * * * \\
(2.97)\end{array}$ & $\begin{array}{c}0.358 \\
(1.19)\end{array}$ \\
\hline$\Delta$ PolStab & $\begin{array}{l}0.492^{*} \\
(1.88)\end{array}$ & $\begin{array}{l}0.521 * \\
(1.77)\end{array}$ & $\begin{array}{l}0.422 \\
(1.41)\end{array}$ & $\begin{array}{c}0.576^{* *} \\
(2.23)\end{array}$ \\
\hline$\Delta$ Press & $\begin{array}{l}0.426^{*} \\
(1.88)\end{array}$ & $\begin{array}{c}0.565^{*} \\
(1.97)\end{array}$ & $\begin{array}{c}0.637 * * \\
(2.46)\end{array}$ & $\begin{array}{c}0.689 * * * \\
(2.64)\end{array}$ \\
\hline$\triangle \mathrm{GDPPC}$ & $\begin{array}{c}0.334 * * \\
(2.13)\end{array}$ & $\begin{array}{c}0.547 * * * \\
(2.93)\end{array}$ & $\begin{array}{c}0.480^{* *} \\
(2.38)\end{array}$ & $\begin{array}{l}0.177 \\
(1.32)\end{array}$ \\
\hline Constant & $\begin{array}{c}0.628 * * * \\
(2.75)\end{array}$ & $\begin{array}{c}0.841 * * * \\
(4.52)\end{array}$ & $\begin{array}{c}0.937 * * * \\
(3.86)\end{array}$ & $\begin{array}{c}0.468 * * * \\
(2.93)\end{array}$ \\
\hline Number of Observations & 264 & 616 & 440 & 616 \\
\hline Adj. R-square & 0.57 & 0.59 & 0.51 & 0.55 \\
\hline Country fixed effects & Yes & Yes & Yes & Yes \\
\hline Year fixed effects & Yes & Yes & Yes & Yes \\
\hline
\end{tabular}


Table 6

Investor Protection Standards and Equity Foreign Bias of Global Fund

$$
\Delta I P S_{j t}=\alpha+\beta_{1} \cdot \Delta G F_{-} F B_{j t}+\beta_{2} . \Delta C t l s_{j t}+\beta_{3} . T F E_{t}+\beta_{4} \cdot C F E_{j}+\epsilon_{j t}
$$

This table reports the estimates of four specifications of equation (15). In each specification the dependent variable is one of the four measures of investor protection (i.e. Firm_Gov, Inv_file, SIPI_WBDB and $A L T_{-} W B G I$ ) as defined in the notes to Table 1 . The explanatory variable of key interest is $G F_{-} F B$, also defined in the notes to Table 1 . All the control variables are defined in the notes to Table 2. All variables are used as first difference. The $t$-statistics, reported in parentheses, are based on double clustered standard errors (clustering done at the country and year level). The $t$-statistics, reported in parentheses, are based on double clustered standard errors (clustering done at the country and year level). For tractable interpretation, all the coefficients are reported as elasticity and the statistical significance is reported against $10 \%(*), 5 \%(* *)$ and $1 \%(* * *)$ significance levels respectively.

\begin{tabular}{|c|c|c|c|c|}
\hline & $\begin{array}{l}\text { Model (1) } \\
\text { Firm_Gov }\end{array}$ & $\begin{array}{l}\text { Model (2) } \\
\text { Inv_file }\end{array}$ & $\begin{array}{c}\text { Model (3) } \\
\text { SIPI_WBDB }\end{array}$ & $\begin{array}{c}\text { Model (4) } \\
\text { ALT_WBGI }\end{array}$ \\
\hline$\Delta \mathrm{GF} \_\mathrm{FB}$ & $0.357 * * *$ & $0.493 * * *$ & $0.501 * * *$ & $0.564 * * *$ \\
\hline & $(2.51)$ & $(2.62)$ & $(2.87)$ & (3.14) \\
\hline$\Delta$ Retn_1 & $\begin{array}{l}0.432 \\
(1.45)\end{array}$ & $\begin{array}{c}0.652 * * \\
(2.13)\end{array}$ & $\begin{array}{l}0.370 \\
(1.39)\end{array}$ & $\begin{array}{c}0.588^{*} \\
(1.79)\end{array}$ \\
\hline$\Delta$ Turn & $\begin{array}{c}0.305^{* *} \\
(2.47)\end{array}$ & $\begin{array}{c}0.429 * * * \\
(2.63)\end{array}$ & $\begin{array}{c}0.282^{* *} * \\
(2.03)\end{array}$ & $\begin{array}{c}0.518 * * * \\
(3.11)\end{array}$ \\
\hline$\Delta \mathrm{MGDP}$ & $\begin{array}{l}0.690 \\
(1.36)\end{array}$ & $\begin{array}{c}0.849 * * \\
(2.14)\end{array}$ & $\begin{array}{c}0.791^{*} \\
(1.76)\end{array}$ & $\begin{array}{l}0.588 \\
(1.23)\end{array}$ \\
\hline$\Delta \operatorname{Infl}$ & $\begin{array}{c}-0.486^{* * *} \\
(-2.47)\end{array}$ & $\begin{array}{l}-0.377 \\
(-1.40)\end{array}$ & $\begin{array}{c}-0.502 * * * \\
(-2.93)\end{array}$ & $\begin{array}{l}-0.254 \\
(-1.07)\end{array}$ \\
\hline$\Delta \mathrm{LSMI}$ & $\begin{array}{c}0.464 * * * \\
(2.58)\end{array}$ & $\begin{array}{c}0.327^{*} \\
(1.73)\end{array}$ & $\begin{array}{c}0.472 * * * \\
(3.09)\end{array}$ & $\begin{array}{c}0.542 * * * \\
(3.57)\end{array}$ \\
\hline$\Delta$ Tobinq & $\begin{array}{l}0.376 \\
(1.56)\end{array}$ & $\begin{array}{c}0.562 * * * \\
(2.73)\end{array}$ & $\begin{array}{c}0.583 * * * \\
(2.98)\end{array}$ & $\begin{array}{l}0.354 \\
(1.25)\end{array}$ \\
\hline$\Delta$ PolStab & $\begin{array}{l}0.461 \\
(1.38)\end{array}$ & $\begin{array}{l}0.483 \\
(1.53)\end{array}$ & $\begin{array}{l}0.347 \\
(1.22)\end{array}$ & $\begin{array}{c}0.518^{* *} \\
(2.39)\end{array}$ \\
\hline$\Delta$ Press & $\begin{array}{c}0.569 * * \\
(2.07)\end{array}$ & $\begin{array}{c}0.718 * * * * \\
(2.51)\end{array}$ & $\begin{array}{c}0.753 * * * \\
(2.71)\end{array}$ & $\begin{array}{c}0.796 * * * \\
(2.83)\end{array}$ \\
\hline$\Delta \mathrm{GDPPC}$ & $\begin{array}{c}0.202^{* *} \\
(2.08)\end{array}$ & $\begin{array}{c}0.485^{* * * *} \\
(2.73)\end{array}$ & $\begin{array}{c}0.492 * * * \\
(2.59)\end{array}$ & $\begin{array}{l}0.127 \\
(1.14)\end{array}$ \\
\hline Constant & $\begin{array}{c}0.735 * * * \\
(3.36)\end{array}$ & $\begin{array}{c}0.793 * * * \\
(3.67)\end{array}$ & $\begin{array}{c}0.786 * * * \\
(3.45)\end{array}$ & $\begin{array}{c}0.343 * * * \\
(2.76)\end{array}$ \\
\hline Number of Observations & 264 & 616 & 440 & 616 \\
\hline Adj. R-square & 0.48 & 0.57 & 0.53 & 0.56 \\
\hline Country fixed effects & Yes & Yes & Yes & Yes \\
\hline Year fixed effects & Yes & Yes & Yes & Yes \\
\hline
\end{tabular}


Table 7

\section{Robustness tests}

This table shows the results of two robustness tests. Four specifications of the models are estimated. In each specification the dependent variable is one of the four measures of investor protection (Firm_Gov, Inv_file, SIPI_WBDB, $A L T_{-} W B G I$ ) as defined in the notes to Table 1 . The explanatory variables of main interest in each of the four regressions are $C P I S \_H B, C P I S \_F B$, and $G F_{-} F B$ measures, also defined in the notes to Table 1 . All regression specifications include control variables as defined in the notes to Table 2. Panel A presents the coefficients estimated using the first difference Dynamic GMM panel model. Panel B presents the shock based estimations, employing the 2010 sovereign debt crisis as the exogenous shock which affected the treatment group of GIIPS Eurozone countries (Greece, Italy, Ireland, Portugal and Spain) more than the control group of non-GIIPS Eurozone countries. The $t$ statistics, reported in parentheses, are based on double clustered standard errors (clustering done at the country and year levels). For tractable interpretation, all the coefficients are reported as partial elasticity and the statistical significance is reported against $10 \%(*), 5 \%(* *)$ and $1 \%(* * *)$ significance levels.

Panel A: Dynamic GMM (Equation 16, see the text)

\begin{tabular}{lcccc}
\hline & Model (1) & Model (2) & Model (3) & Model (4) \\
& Firm_Gov & Inv_file & SIPI_WBDB & ALT_WBGI \\
\hline$\Delta$ CPIS_HB_1 & $-0.412^{* * *}$ & $-0.569^{* * *}$ & $-0.572 * * *$ & $-0.625^{* * * *}$ \\
& $(-3.71)$ & $(-3.15)$ & $(-3.96)$ & $(-3.38)$ \\
$\Delta$ CPIS_FB_1 & $0.522^{* * *}$ & $0.689 * * *$ & $0.472^{* * *}$ & $0.597 * * *$ \\
& $(3.43)$ & $(4.68)$ & $(3.59)$ & $(4.44)$ \\
$\Delta$ GF_FB_1 & $0.562 * * *$ & $0.578^{* * *}$ & $0.731 * * *$ & $0.784 * * *$ \\
& $(3.11)$ & $(4.23)$ & $(3.78)$ & $(2.98)$ \\
Adj. R-square & 0.38 & 0.48 & 0.41 & 0.43 \\
Difference Hansen J & 0.37 & 0.45 & 0.28 & 0.51 \\
statistics & & & & \\
Controls including country & & & & \\
and year fixed effects & Yes & Yes & Yes & Yes \\
\hline
\end{tabular}

Panel B: Shock Based Estimations (Equation 17, see the text)

\begin{tabular}{lcccc}
\hline & Model (1) & Model (2) & Model (3) & Model (4) \\
& Firm_Gov & Inv_file & SIPI_WBDB & ALT_WBGI \\
\hline CPIS_HB & $-0.331 * * *$ & $-0.617 * * *$ & $-0.549^{* * *}$ & $-0.641^{* * *}$ \\
& $(-4.27)$ & $(-2.93)$ & $(-3.34)$ & $(-4.46)$ \\
CPIS_FB & $0.653^{* * *}$ & $0.714^{* * *}$ & $0.575^{* * *}$ & $0.632^{* * *}$ \\
& $(4.75)$ & $(3.17)$ & $(2.86)$ & $(3.49)$ \\
GF_FB & $0.596^{* * *}$ & $0.629 * * *$ & $0.722^{* * *}$ & $0.813^{* * *}$ \\
& $(4.23)$ & $(3.78)$ & $(3.47)$ & $(4.26)$ \\
\hline
\end{tabular}




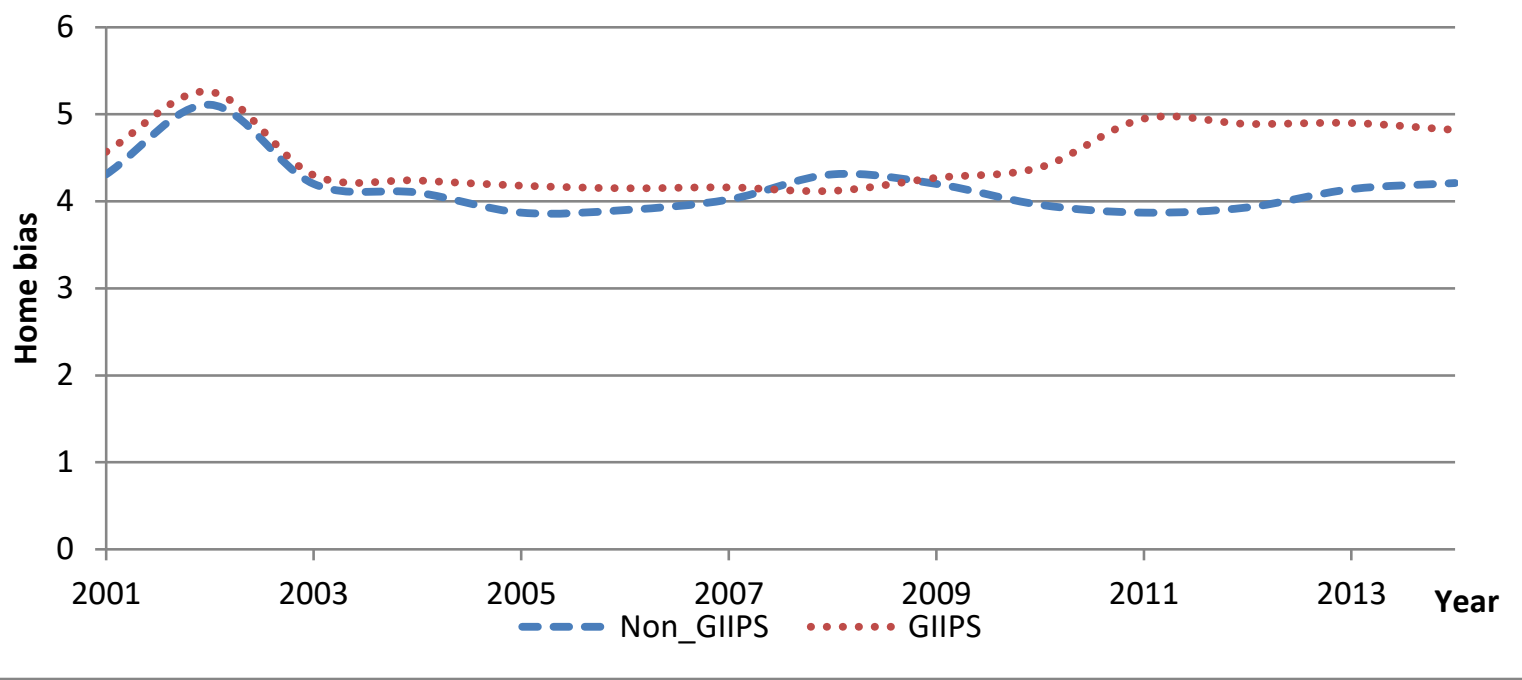

Notes: Figure 1 shows the annual average home bias measure (i.e. tendency of domestic portfolio investors to over or under allocate their own domestic market relative to the ICAPM benchmark) for the GIIPS (Greece, Italy, Ireland, Portugal and Spain) and non-GIIPS euro countries. The objective is to gauge how the GIIPS countries experienced an increase in their home bias compared to non-GIIPS countries during the recent 2010 European sovereign debt crisis.

Figure 2: Yearly foreign bias in non-GIIPS and GIIPS countries

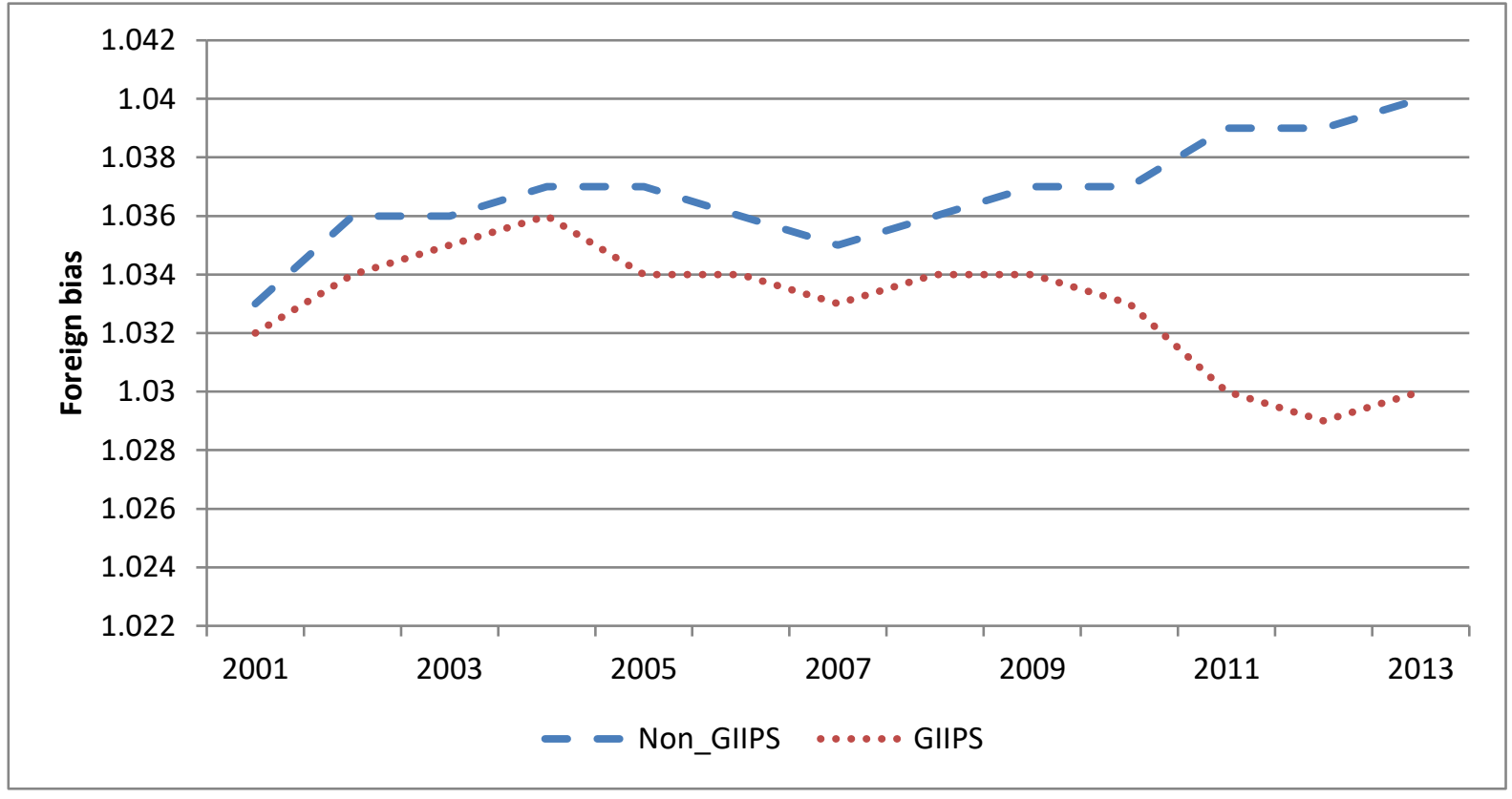

Notes: Figure 2 shows the annual average foreign bias (i.e. tendency of foreign portfolio investors to over or under allocate a non-resident country relative to the ICAPM benchmark) for the GIIPS (Greece, Italy, Ireland, Portugal and Spain) and non-GIIPS Eurozone countries. The objective is to gauge how the GIIPS countries suffered a decline in their foreign bias proxy compared to non-GIIPS countries during the recent 2010 European sovereign debt crisis. 


\section{Appendix}

Table A1

Definitions of Variables

\begin{tabular}{|c|c|c|}
\hline Variable & Description & Data source \\
\hline Firm_Gov & Firm-level corporate governance indexes & $\begin{array}{l}\text { Obtained data from two sources; Developed markets from } \\
\text { Aggarwal et al. (2011) and emerging markets from Alliance } \\
\text { Bernstein Capital Emerging Market Universe }\end{array}$ \\
\hline Inv_file & Investment profile & International Country Risk Guide \\
\hline SIPI_WBDB & Strength of Investor Protection Index & World Bank Doing Business \\
\hline ALT_WBGI & Alternative country level investor protection measures & World Bank's World Development Indicator \\
\hline CPIS_HB & $\begin{array}{l}\text { Equity home bias calculated as the log (natural) value of the share of domestic } \\
\text { investors in their own country's stock market capitalization }(j) \text { relative to the country's } \\
\text { world market capitalization weight }\end{array}$ & $\begin{array}{l}\text { Coordinated Portfolio Investment Survey (CPIS) of International } \\
\text { Monetary Fund (IMF) }\end{array}$ \\
\hline CPIS_FB & $\begin{array}{l}\text { Equity foreign bias measure using the world-market-based, free float adjusted method } \\
\text { (see Dahlquist et al., 2003; Kho et al., 2009; Mishra and Ratti, 2013) }\end{array}$ & CPIS of IMF and Morgan Stanley Capital International \\
\hline GF_FB & Equity foreign bias measure using global fund data & Emerging Portfolio Fund Research (EPFR) \\
\hline Retn_1 & Previous year's average of monthly returns measured by MSCI total return index. & Morgan Stanley Capital International (MSCI) \\
\hline Turn & $\begin{array}{l}\text { Turnover ratio measured as the ratio of total value of stocks traded to market } \\
\text { capitalization }\end{array}$ & MSCI \\
\hline MGDP & Ratio of market capitalization scaled by GDP & World Bank’s World Development Indicator \\
\hline Infl & $\begin{array}{l}\text { Annual inflation index of a country. Annual inflation index of each country is sourced } \\
\text { from WDI }\end{array}$ & World Bank's World Development Indicator \\
\hline LSMI & $\begin{array}{l}\text { Log stock market integration measured as the ratio of a country's annual exports plus } \\
\text { imports divided by GDP }\end{array}$ & World Bank’s World Development Indicator \\
\hline Tobinq & $\begin{array}{l}\text { Tobinq measure constructed by taking the ratio of each country's constituent firms' } \\
\text { total liabilities plus equity market value to the book values of the firms' assets }\end{array}$ & Morgan Stanley Capital International and Thompson Reuters \\
\hline PolStab & Political stability rating index (0-100), higher value of index reflecting higher stability & Political Risk Services Group’s ICRG \\
\hline Press & $\begin{array}{l}\text { Press freedom which takes a value of } 0 \text { (lowest degree of press freedom) and } 100 \\
\text { (highest degree of press freedom) }\end{array}$ & Maintained by World Bank Governance Indicator - World Bank \\
\hline GDPPC & Gross domestic product per capita. & World Bank's World Development Indicator \\
\hline
\end{tabular}

